\title{
Article \\ Inventory and Distribution Characteristics of Large-Scale Landslides in Baoji City, Shaanxi Province, China
}

\author{
Lei Li ${ }^{1,2,3}$, Chong $X u^{1,2, *}$, Xiwei $X u^{1,2}$, Zhongjian Zhang ${ }^{3}$ and Jia Cheng ${ }^{1,2}$ \\ 1 National Institute of Natural Hazards, Ministry of Emergency Management of China, Beijing 100085, China; \\ leiL_cugb@126.com (L.L.); xiweixu@vip.sina.com (X.X.); jiacheng@ninhm.ac.cn (J.C.) \\ 2 Key Laboratory of Compound and Chained Natural Hazards Dynamics, \\ Ministry of Emergency Management of China, Beijing 100085, China \\ 3 School of Engineering and Technology, China University of Geosciences (Beijing), Beijing 100083, China; \\ zzjcas@126.com \\ * Correspondence: chongxu@ninhm.ac.cn
}

check for updates

Citation: Li, L.; Xu, C.; Xu, X.; Zhang, Z.; Cheng, J. Inventory and Distribution Characteristics of Large-Scale Landslides in Baoji City, Shaanxi Province, China. ISPRS Int. J. Geo-Inf. 2022, 11, 10. https://doi.org/ 10.3390 /ijgi11010010

Academic Editors: Milan Konecny,

Jie Shen, Zhenlong Li and

Wolfgang Kainz

Received: 15 November 2021

Accepted: 26 December 2021

Published: 29 December 2021

Publisher's Note: MDPI stays neutral with regard to jurisdictional claims in published maps and institutional affiliations.

Copyright: (C) 2021 by the authors. Licensee MDPI, Basel, Switzerland. This article is an open access article distributed under the terms and conditions of the Creative Commons Attribution (CC BY) license (https:// creativecommons.org/licenses/by/ $4.0 /)$.

\begin{abstract}
Inventories of historical landslides play an important role in the assessment of natural hazards. In this study, we used high-resolution satellite imagery from Google Earth to interpret large landslides in Baoji city, Shaanxi Province on the southwestern edge of the Loess Plateau. Then, a comprehensive and detailed map of the landslide distribution in this area was prepared in conjunction with the historical literature, which includes 3440 landslides. On this basis, eight variables, including elevation, slope, aspect, slope position, distance to the fault, land cover, lithology and distance to the stream were selected to examine their influence on the landslides in the study area. Landslide number density (LND) and landslide area percentage (LAP) were used as evaluation indicators to analyze the spatial distribution characteristics of the landslides. The results show that most of the landslides are situated at elevations from 500 to $1400 \mathrm{~m}$. The LND and LAP reach their peaks at slopes of $10-20^{\circ}$. Slopes facing WNW and NW directions, and middle and lower slopes are more prone to sliding with higher LND and LAP. LND and LAP show a decreasing trend as the distance to the fault or stream increases, followed by a slow rise. Landslides occur primarily in the areas covered by crops. Regarding lithology, the regions covered by the Quaternary loess and Cretaceous gravels are the main areas where landslides occur. The results would be helpful for further understanding the developmental characteristics and spatial distribution of landslides on the Loess Plateau, and also provide a support to subsequent landslide susceptibility mapping in this region.
\end{abstract}

Keywords: Loess Plateau; Baoji city; large landslide inventory; visual interpretation; Google Earth; GIS; spatial analysis

\section{Introduction}

Landslides are a common geological hazard, causing serious casualties and economic losses every year [1,2]. Regional historical landslide inventories play an important role in the assessment of natural hazards. For example, the Oso landslide occurred in northwest Washington State on 22 March 2014, leading to devastating loss of life and destruction of property. The study of Kim et al. [3] on this event showed that a landslide had already occurred there in 2006. Compiling a complete historical landslide database is useful for analyzing the spatial distribution of landslides and their impact on the evolution of geomorphology and rivers [4]. Under the same conditions, the areas affected by previous landslides may become unstable in the future, thus moving from past records to future projections $[5,6]$. In many countries or regions around the world, the inventory of regional historical landslides has been completed, which is gradually maturing in terms of content, structure, accuracy and completeness. For example, the EM-DAT (International Disaster Database) was collated by KU Leuven [7]. Kir et al. [8] established a new publicly available global landslide catalogue, covering 124 countries and territories. Prior to the widespread 
use of the digital elevation model (DEM), Radbruch-Hall et al. [9] produced an overview map of landslides around the United States. Ohmori and Sugai [10] compiled a dataset of 3424 landslides larger than $10^{4} \mathrm{~m}^{2}$ in the Akashi Mountains, central Japan. In total, 22 of the 37 countries in Europe have national landslide databases [11]. Pennington et al. [12] created the U.K.'s national landslide database, which was enriched by Taylor et al. [13]. Damm and Klose [14] created the landslide database in Germany. Guzzetti et al. [15] compiled a landslide database spanning 1279-1999 for Italy. Sabatakakis et al. [16] created the landslide database in Greece. These landslide databases permit to perform further statistics on the frequency of landslide occurrence and analysis of spatio-temporal cluster characteristics [17], susceptibility mapping, hazard assessment and so forth.

Brunsden [18] wrote: The best friend of landslide researchers remains the aerial photographs. Everyone is familiar with the power of this medium, and there are few studies that do not use some form of aerial photographs to discern landslides. Along with the rapid development of the remote sensing technology, visual interpretation has become quite popular due to the high resolution, multi-temporal and high coverage of remote sensing images [19]. The vertical features introduced by Google Earth imagery amplify the morphological appearance of the terrain and reveal subtle topographic variations, which is helpful to identify and interpret topographic features of typical landslides [20].

The Loess Plateau is one of the most earthquake-prone areas in China due to its complex geological background and intense tectonic activity, leading to a large number of earthquake landslides [21]. The vertical joints, macropores of loess and the shrinkage in contact with water also provide favorable conditions for slope failures. Combining geological hazard reports and field surveys, Peng et al. [22] compiled a landslide distribution map of the Loess Plateau containing 14,544 landslides. Based on Google Earth, Xu et al. [23] interpreted more than 80,000 landslides, which is the largest list of landslides in the Loess Plateau. In addition to the inventory of landslides over the entire Loess Plateau, Zhuang et al. [24] recorded 4122 landslides in Shaanxi Province through a combination of geological hazard reports and field investigations. Zhang et al. [25] compiled 293 landslides in the Baota District, Yan'an City with visual interpretation of high-resolution satellite images, ground surveys and mapping.

Baoji city, located in the southwest corner of the Loess Plateau, is one typical area with landslide occurrences. To date, there is little detailed cataloging of the landslides for this district. To fill this gap, this work prepared a detailed landslide inventory map of this area based on visual interpretation of high-resolution satellite images from Google Earth. The accuracy of the interpretation was verified by the existing literature and hazard records. Finally, we compiled a detailed inventory of large-scale landslides in this area and conducted a statistical analysis of their influencing factors to characterize the distribution pattern of large-scale historical landslides in Baoji.

\section{Study Area}

The study area is the whole city of Baoji, located in the south of Shaanxi Province with a total area of $18,137 \mathrm{~km}^{2}$. Regarding regional tectonics, Baoji lies at the boundary between the Yangtze and Ordos plates, with highly variable landforms, surrounded by mountains to the south, west and north, and expanding eastward with the Wei River as the central axis (Figure 1a). Meanwhile, Baoji is located in the compound intersection of the Qinling latitudinal tectonic system and other tectonic systems, with the characteristics of north-south connection and east-west transition. It can be divided into three geological tectonic units: the Qinling fold belt in the south, the Weihe fault basin in the middle and the Ordos syncline region in the north [26] (Figure 1b). In terrain, Baoji is dominated by mountains and hills, inclining from southwest to northeast, with an elevation of $3719 \mathrm{~m}$ down to $404 \mathrm{~m}$, about $1350 \mathrm{~m}$ on average. The several streams are the tributaries of the Wei River, the largest drainage in this area. 

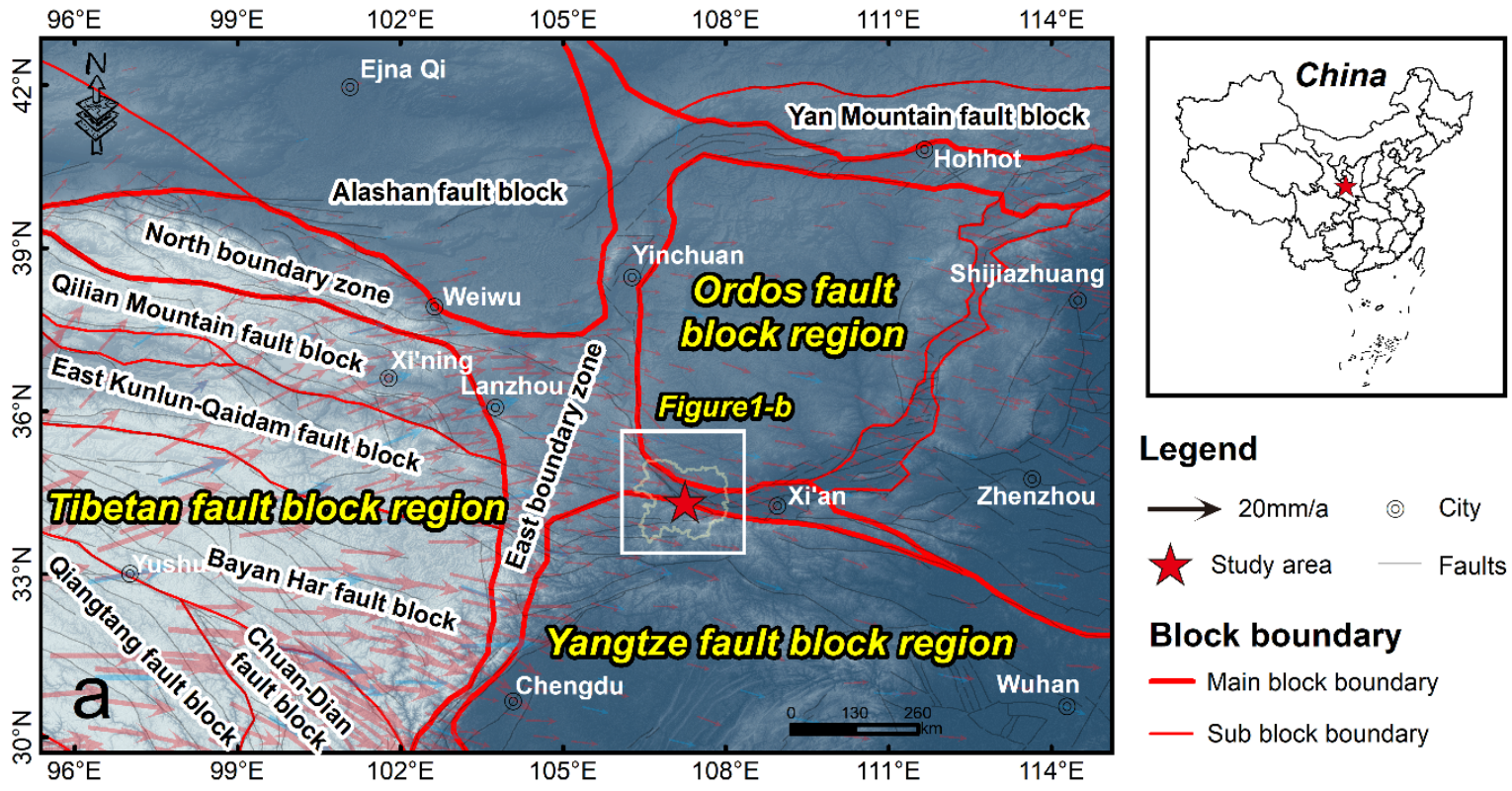

\section{Legend}

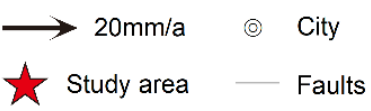

\section{Block boundary}

- Main block boundary

- Sub block boundary

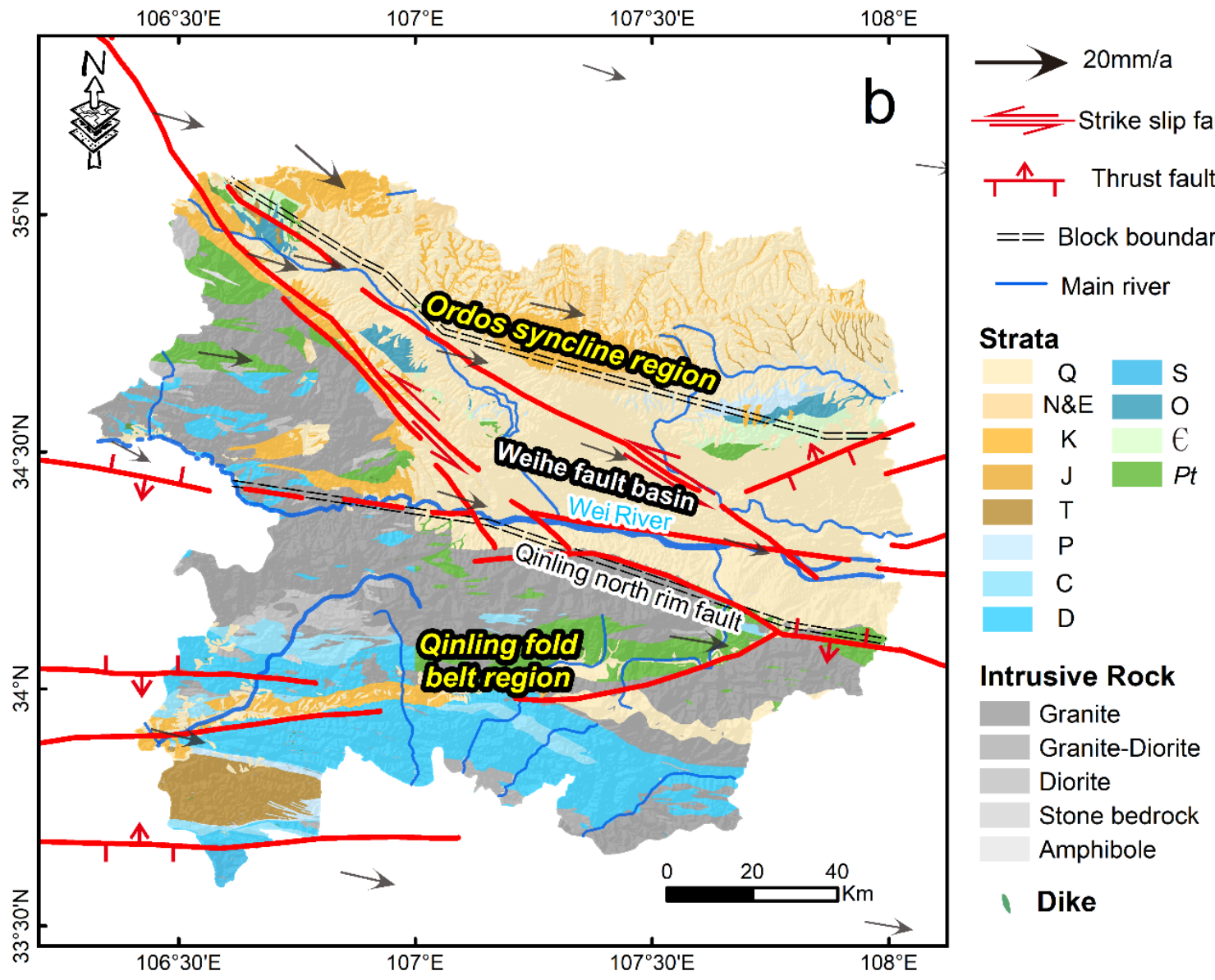

Figure 1. Geological setting of Baoji. (a) Baoji is located at the plate junction, regional GPS velocity (red represents the campaign stations, time period: 2009-2014; blue represents continuous stations, time period: 1998-2014). (b) Distribution of lithology in the study area (according to stratigraphic ages), regional GPS velocity (campaign stations, time period: 2009-2014). The GPS velocity (a,b) is from Zhao et al. [27], fault block information (a) is from Deng et al. [28]. Strata: Q-Quaternary, N\&ETertiary, K-Cretaceous, J-Jurassic, T-Triassic, P-Permian, C-Carboniferous, D-Devonian, $\mathrm{S}$-Silurian, $\mathrm{O}$-Ordovician, $\in$-Cambrian, $\mathrm{Pt}$ - -Proterozoic. 
The northeastern part of Baoji is located in the Ordos Plate, which is mainly covered by a thick layer of Quaternary loess, usually between 0.075 and $0.25 \mathrm{~mm}$ in particle size [29]. Figure $1 \mathrm{~b}$ shows the main strata and lithology of the study area, which can be divided into 12 types of rock groups according to stratigraphic ages (Table 1), including basement of Pre-Cambrian, limestone and sandstone from Cambrian to Silurian, biotite-quartz schist and granitic sandstone from Devonian to Permian, sandstone and shale from Triassic to Cretaceous, shale and marl of Tertiary, and loess of Quaternary. There are also five types of intrusive rocks: biotite granite, quartz diorite, hornblende pyroxenite (bedrock) and hornblende gneiss. Table 2 summarizes the historical earthquakes in Baoji City and neighboring areas [30], and Figure 2 shows the geographical location of the earthquake sites. In terms of climate, Baoji belongs to a semi-humid climate zone in the warm temperate zone of mid-latitudes, a continental monsoon climate type, with a mean annual temperature of $12.9^{\circ} \mathrm{C}$ and an average annual rainfall of $\sim 600 \mathrm{~mm}$; we collected data from six meteorological stations (Figure 2) in and around the study area for the last 10 years, and then plotted the annual average temperature and annual average precipitation in Figure 3.

Table 1. Twelve stratigraphic ages and corresponding lithologies.

\begin{tabular}{lll}
\hline No. & Strata & Main Lithologies \\
\hline 1 & Quaternary (Q) & Fluvial loess, Aeolian loess, Sandy clay \\
2 & Tertiary (N\&E) & Sandy conglomerates, Siltstone \\
3 & Cretaceous (K) & Sandstone, Conglomerate, Mudstone clamp sandstone \\
4 & Jurassic (J) & Silicarenite, Sandy shale, Coal seam \\
5 & Triassic (T) & Sandy shale, Coaly shale, Mudstone \\
6 & Permian (P) & Sandstone with shale, Quartzose sandstone, Granite \\
7 & Carboniferous (C) & Silicarenite, Carbonaceous sandstone \\
8 & Devonian (D) & Silty slate, Sedimentary limestone, Dolomitic marble \\
9 & Silurian (S) & Siliceous limestone, Limestone, Phyllite \\
10 & Ordovician (O) & Argillaceous limestone, Dolomitic limestone \\
11 & Cambrian (E) & Dolomitic limestone, Shale, Quartzite \\
12 & Proterozoic (Pt) & Di-mica quartz schist, Graphite marble, Black mica gneiss \\
\hline
\end{tabular}

Table 2. Historical earthquake catalog of Baoji City and neighboring areas (100 km).

\begin{tabular}{ccccc}
\hline Site & Time (Year) & Magnitude (Ms) & Longitude $\left(^{\circ}\right.$ ) & Latitude $\left(^{\circ}\right.$ ) \\
\hline Qishan & 780 B.C. & 7 & 107.8 & 34.5 \\
Lantian & 35 B.C. & 5.75 & 109 & 34.3 \\
Tianshui & 416 & 5 & 105.6 & 34.5 \\
Tianshui-Longxian & 600 & 6 & 106.5 & 34.5 \\
Tianshui & 734 & 7 & 105.6 & 34.6 \\
Qishan & 1307 & 5 & 107.6 & 34.5 \\
Xianyang & 1487 & 6.25 & 108.9 & 34.4 \\
Huixian-Tianshui & 1542 & 5 & 106 & 34.2 \\
Xi'an & 1568 & 6.75 & 109 & 34.4 \\
Zhuanglang & 1642 & 6 & 105.9 & 35.4 \\
Lingtai & 1634 & 5.5 & 107.6 & 35.1 \\
Longxian & 1704 & 6 & 107 & 34.9 \\
Guyuan & 1921 & 6.5 & 106.2 & 35.8 \\
Tianshui & 1936 & 6 & 105.7 & 34.2 \\
\hline
\end{tabular}




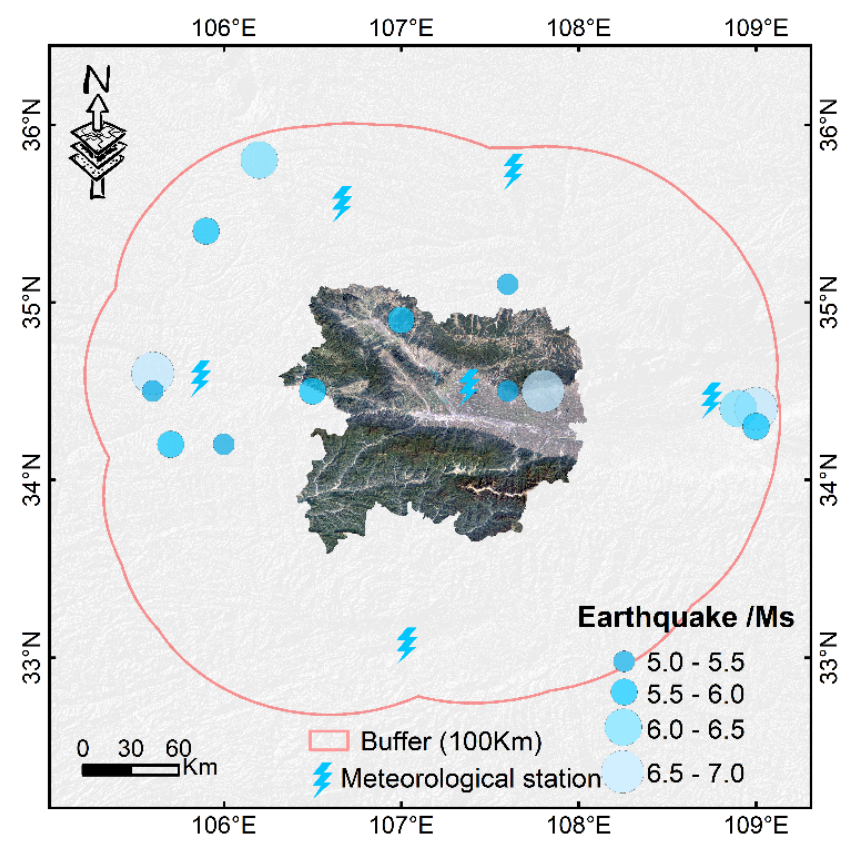

Figure 2. Locations of six meteorological stations and seismic sites.

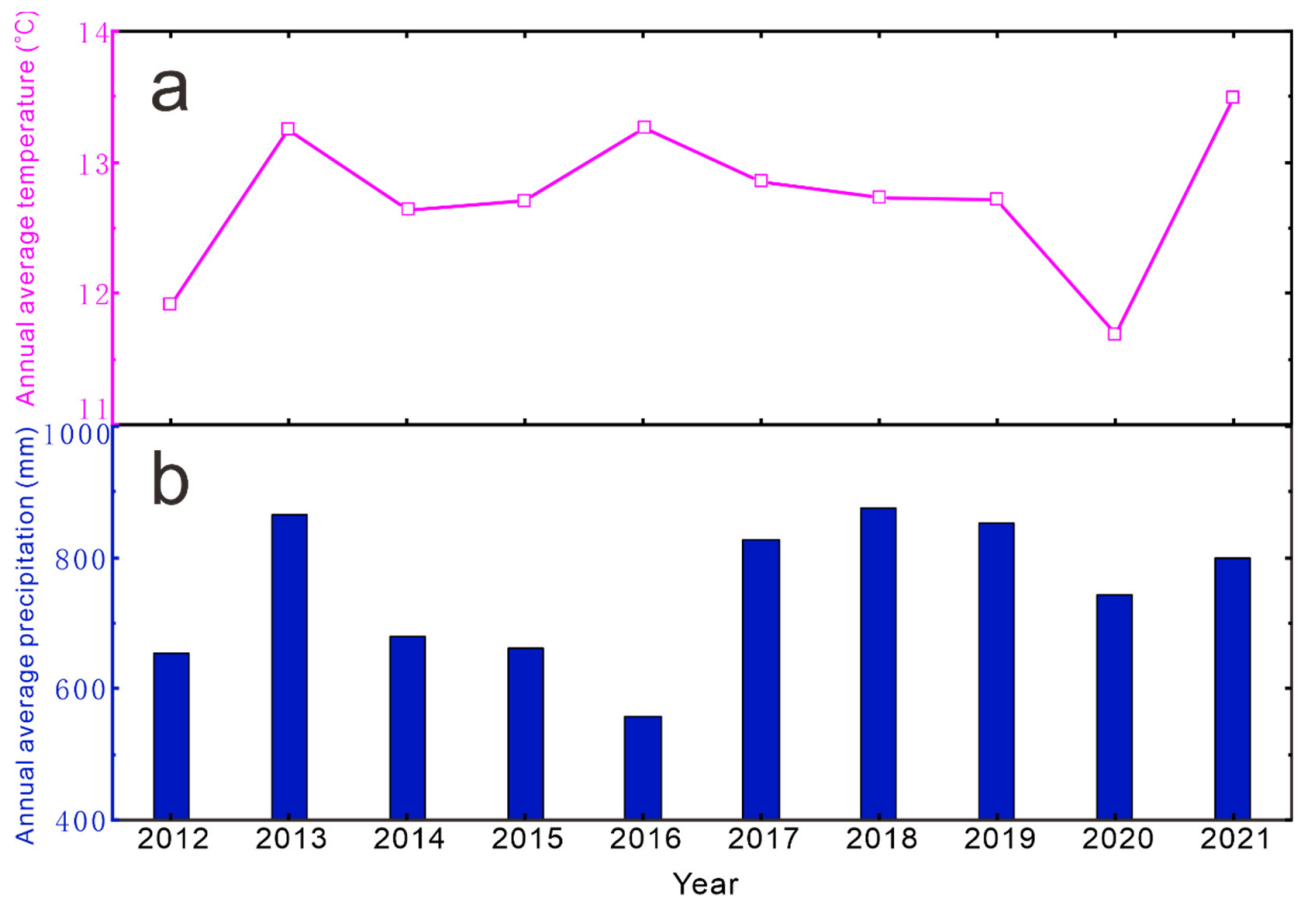

Figure 3. Annual average temperature (a) and annual average precipitation (b) from six meteorological stations (time period:2012-2021) around the study area.

\section{Landslide Inventory}

\subsection{Visual Interpretation}

In recent years, the Google Earth platform has been widely used in landslide investigations [31,32]. It contains available Landsat imagery (30 $\mathrm{m}$ or $15 \mathrm{~m}$ pan-sharpened), orthophotos (0.5-2 m), and high-resolution commercial satellite imagery (SPOT, FORMOSAT2: $0.5-8 \mathrm{~m}$; World View-1 and World View-2, 0.5-2.5 m) [33,34]. The satellite images are continuous and $100 \%$ coverage of the whole study area, and their resolution also meets the requirements for identifying large-scale landslides. This work performed a visual 
interpretation of large landslides in the study area based on Google Earth, which was proven to be an objective and accurate approach in many previous studies $[35,36]$.

Cruden and Varnes [37] suggested that some landslides in the past remain visible in the landscape for thousands of years after they initially moved and then stabilized. Landslides caused by earthquakes or rainfall, with the passage of time, may have been reformed to varying degrees. The vegetation restoration in the study area, however, has little influence on the outlines of historical landslides, which remain clearly visible. To identify the historical landslides, this work relied on geomorphology and morphological characteristics of the landslide body: the back wall of a landslide often shows a lap-chair shape, with obvious curved ridge lines; platform depressions may develop in the middle and rear parts of landslide body; and cracks are distributed in the middle and front edge. On the remote sensing images, they usually present tongue-shaped or circle-chair-shaped features, with irregular step-like distribution on the landslide body [38]. Figure 4 shows four typical large landslides identified in the study area.
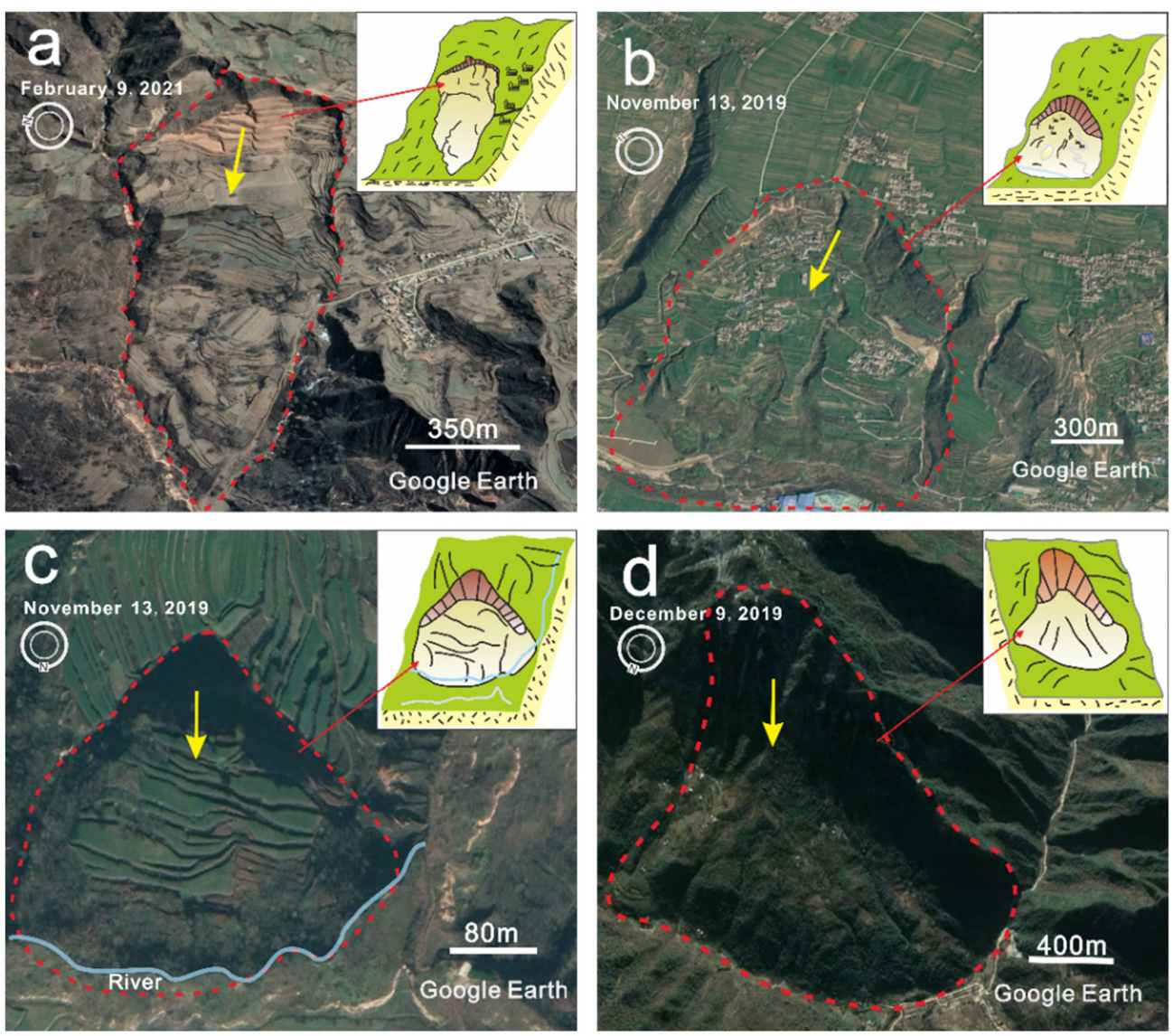

Figure 4. Interpretation of landslides at four sites of the study area. The red box represents the interpreted landslide boundary and yellow arrow represents the sliding direction. Image source: Google Earth. The illustration in the upper right corner of the remote sensing image shows cartoon diagram of the landslide. Site: (a) $\left(35^{\circ} 03^{\prime} 01^{\prime \prime} \mathrm{N}, 106^{\circ} 56^{\prime} 14^{\prime \prime} \mathrm{E}\right),\left(\right.$ b) $\left(34^{\circ} 28^{\prime} 30^{\prime \prime} \mathrm{N}, 107^{\circ} 7^{\prime} 13^{\prime \prime} \mathrm{E}\right)$, (c) $\left(34^{\circ} 30^{\prime} 29^{\prime \prime} \mathrm{N}, 107^{\circ} 8^{\prime} 15^{\prime \prime} \mathrm{E}\right),(\mathrm{d})\left(33^{\circ} 52^{\prime} 25^{\prime \prime} \mathrm{N}, 106^{\circ} 40^{\prime} 50^{\prime \prime} \mathrm{E}\right)$.

\subsection{Inventory of Large Landslides}

A total of 3440 landslides were identified in the study area, with a cumulative extent of $359.5 \mathrm{~km}^{2}$. From the landslide area, 12 landslides, 1021 landslides and 2407 landslides have areas $\geq 10^{6} \mathrm{~m}^{2}, 10^{6} \mathrm{~m}^{2}>$ area $\geq 10^{5} \mathrm{~m}^{2}$ and $10^{5} \mathrm{~m}^{2}>$ area, respectively, accounting for $0.3 \%, 29.7 \%$ and $70 \%$, respectively, of the total number of landslides. The average landslide area is $104,198 \mathrm{~m}^{2}$, and the largest landslide area is approximately $1.71 \times 10^{6} \mathrm{~m}^{2}$, which is located in Feng County in the south of Baoji City. Figure 5 shows the geographic location 
of the landslide sites with different sizes; it can be seen that the number of landslides in the northwestern Long County and around the central Jintai District is the highest, and the overall size of the landslide in the northeastern corner is large. Meanwhile, we collected many typical landslides from historical articles and disaster records (Table 3), which further confirmed the accuracy of the interpretation. The landslides recorded in the articles have more or less the typical characteristics of landslides mentioned in Section 3.1 above.

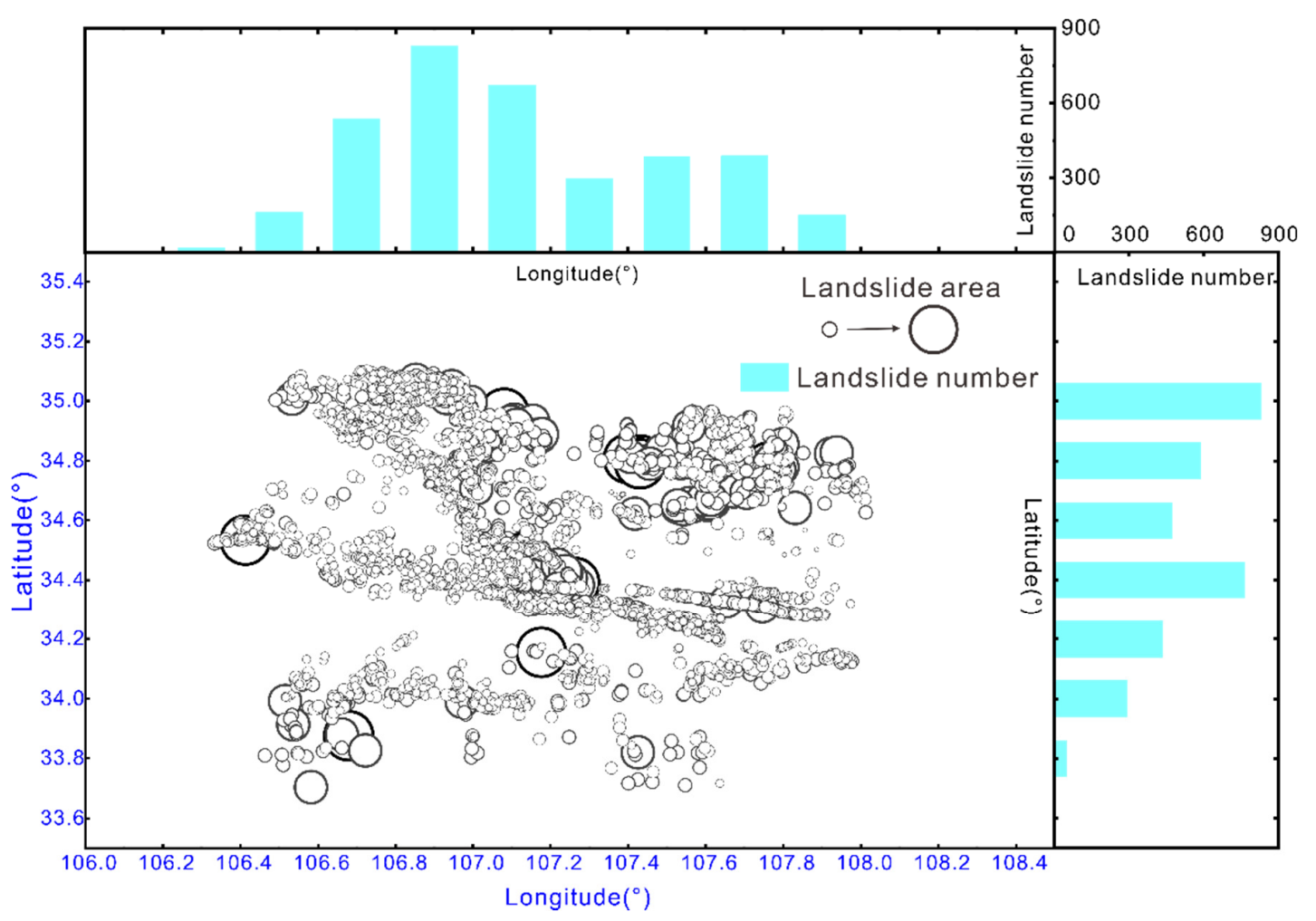

Figure 5. Spatial distributions of landslides identified.

Table 3. Locations of landslides documented in the literature.

\begin{tabular}{ccc}
\hline Name (Landslide) & Longitude & Latitude \\
\hline Yan's shady slope [39] & $107^{\circ} 13^{\prime} 00^{\prime \prime}$ & $34^{\circ} 38^{\prime} 20^{\prime \prime}$ \\
Lijiaxia [39] & $106^{\circ} 56^{\prime} 40^{\prime \prime}$ & $34^{\circ} 57^{\prime} 48^{\prime \prime}$ \\
Black gully gate [39] & $106^{\circ} 34^{\prime} 03^{\prime \prime}$ & $34^{\circ} 58^{\prime} 26^{\prime \prime}$ \\
Yangjia village [40] & $107^{\circ} 43^{\prime} 40^{\prime \prime}$ & $34^{\circ} 18^{\prime} 55^{\prime \prime}$ \\
Gaojia cliff [41] & $107^{\circ} 07^{\prime} 08^{\prime \prime}$ & $34^{\circ} 23^{\prime} 12^{\prime \prime}$ \\
Golden dome temple [41] & $107^{\circ} 07^{\prime} 29^{\prime \prime}$ & $34^{\circ} 23^{\prime} 05^{\prime \prime}$ \\
Bumpy mountain [41] & $107^{\circ} 08^{\prime} 17^{\prime \prime}$ & $34^{\circ} 22^{\prime} 53^{\prime \prime}$ \\
North slope village [42] & $107^{\circ} 17^{\prime} 05^{\prime \prime}$ & $34^{\circ} 22^{\prime} 04^{\prime \prime}$ \\
Liujia stream [43] & $107^{\circ} 05^{\prime} 51^{\prime \prime}$ & $34^{\circ} 24^{\prime} 49^{\prime \prime}$ \\
Zhu plateau [43] & $107^{\circ} 06^{\prime} 33^{\prime \prime}$ & $34^{\circ} 25^{\prime} 01^{\prime \prime}$ \\
\hline
\end{tabular}

\section{GIS Spatial Analysis of Landslides}

\subsection{Influencing Factors}

Referring to the statistics of landslide influencing factors in previous work [44], and considering the purpose of this study, we selected eight influencing factors of landslides, including elevation, slope, aspect, slope position, distance to the fault, land cover, lithology and distance to the stream. The DEM data used were ALOS PALSAR DEM (resolution $12.5 \mathrm{~m}$ ), from which the stream, slope and aspect information were extracted. The relative position index (RPI) was introduced to define the slope position [45]. The RPI of a landslide on the slope is defined as the ratio of the shortest distance from its centroid to the valley 
and the sum of the shortest distances from the point to the valley and ridge (Figure 6a), which was divided into 5 levels (Figure 6b). The fault and lithology data were derived from Deng et al. [46] and a 1:200,000 geological map, separately. The land cover data (resolution $12.5 \mathrm{~m}$, after resampling) were from European Space Agency (ESA).
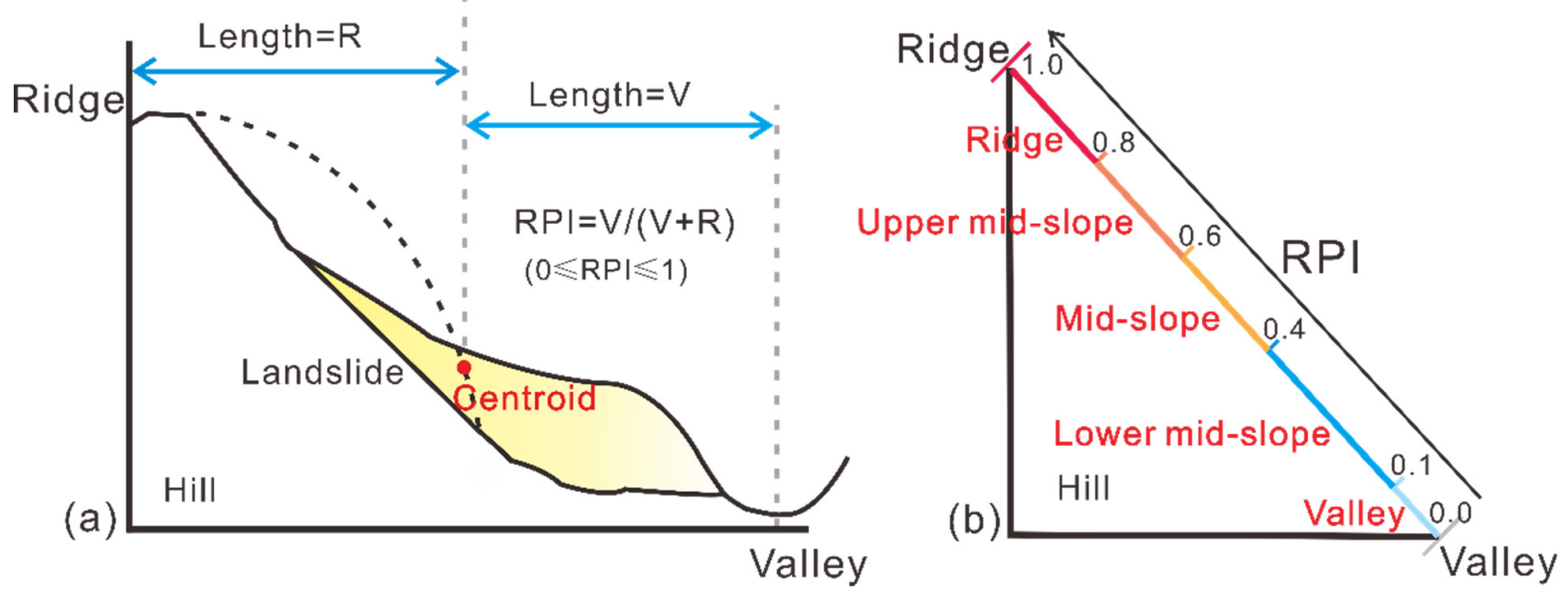

Figure 6. Definition of the RPI (relative position index) (a) and the different RPI values representing the different hill sections (b). The RPI values of [0.0-0.1), [0.1-0.4), [0.4-0.6), [0.6-0.8), [0.8-1.0] represent the valley, lower mid-slope, mid-slope, upper mid-slope and ridge, respectively, of a hill.

\subsection{Statistics and Analysis}

Besides the RPI, the location of a landslide is determined in more detail by using its elevation, distance from the river (Figures 7 and 8), slope and aspect (Figures 9 and 10). Zhuang et al. [24] found that the overall distribution of landslides in the Loess Plateau has a certain clustering characteristic, i.e., landslides may appear in clusters or bands. In the process of spatial analysis, a similar phenomenon was noted, which was inferred that the zonal distribution of landslides is influenced by faults (Figure 11), and the aggregated distribution may be influenced by land-use types (Figure 12).

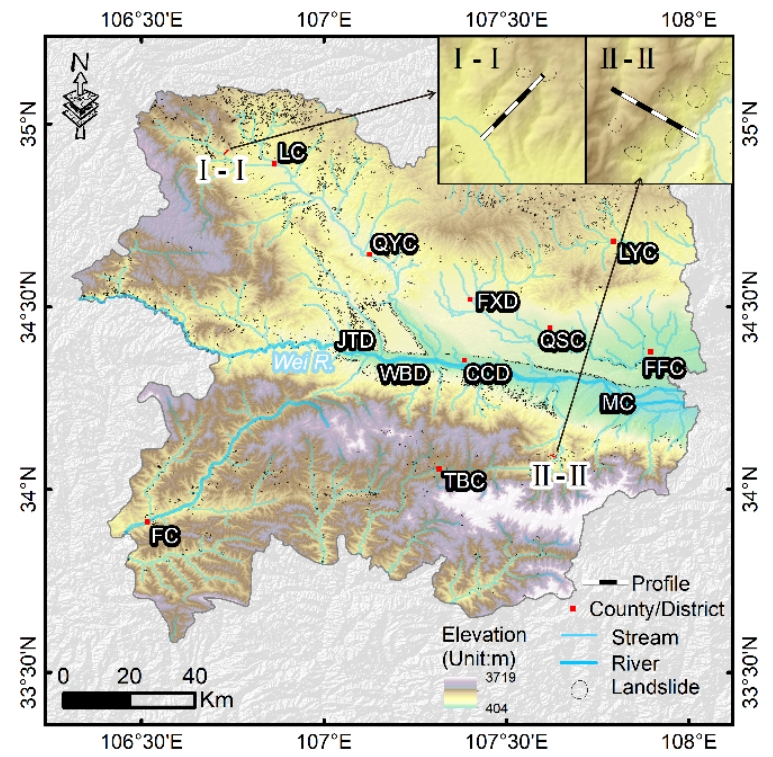

Figure 7. Elevation in the study area and distribution of districts and counties. FC-Feng County, QYC—Qianyang County, JTD—Jintai District, WBD—Weibin District, TBC—Taibai County, CCD— Chencang District, FXD—Fengxiang District, QSC—Qishan County, MC—Mei County, LYC—Linyou County, FFC-Fufeng County. 


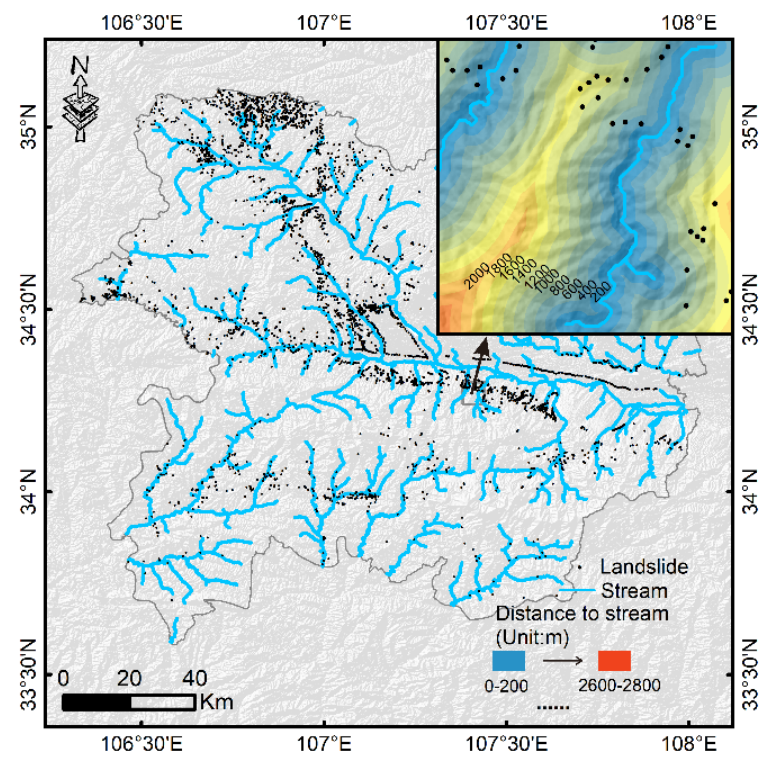

Figure 8. Stream distribution in the study area. The illustration in the upper right corner indicates the ranked distance interval from stream.
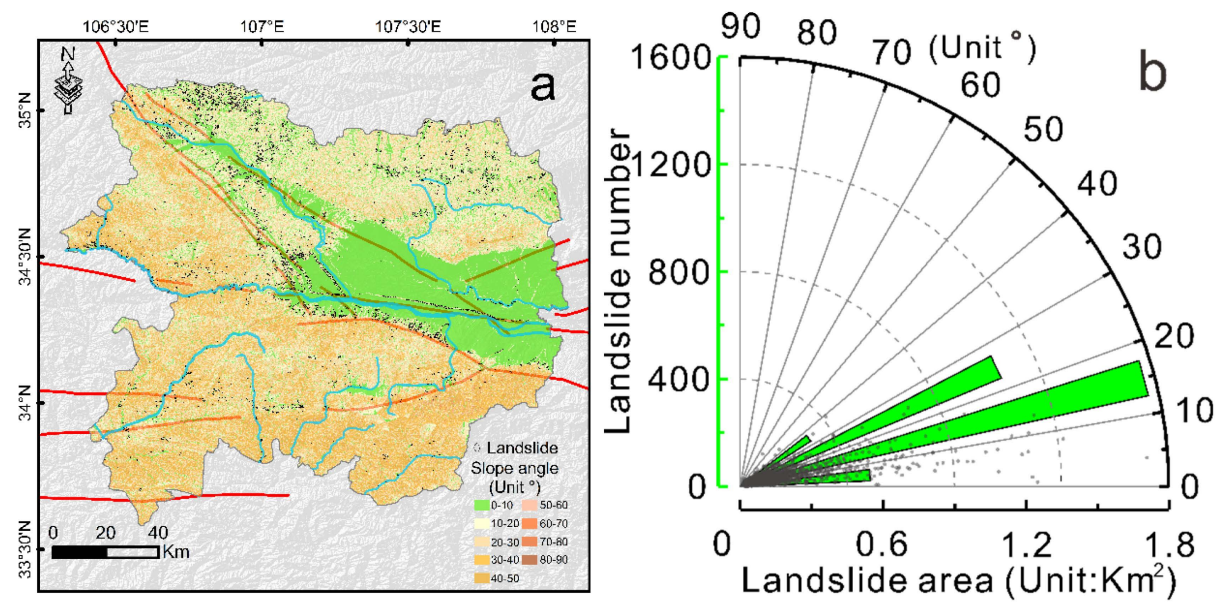

Figure 9. (a) Slope distribution in the study area. (b) Landslide distribution in respect to slope angle and landslide area.
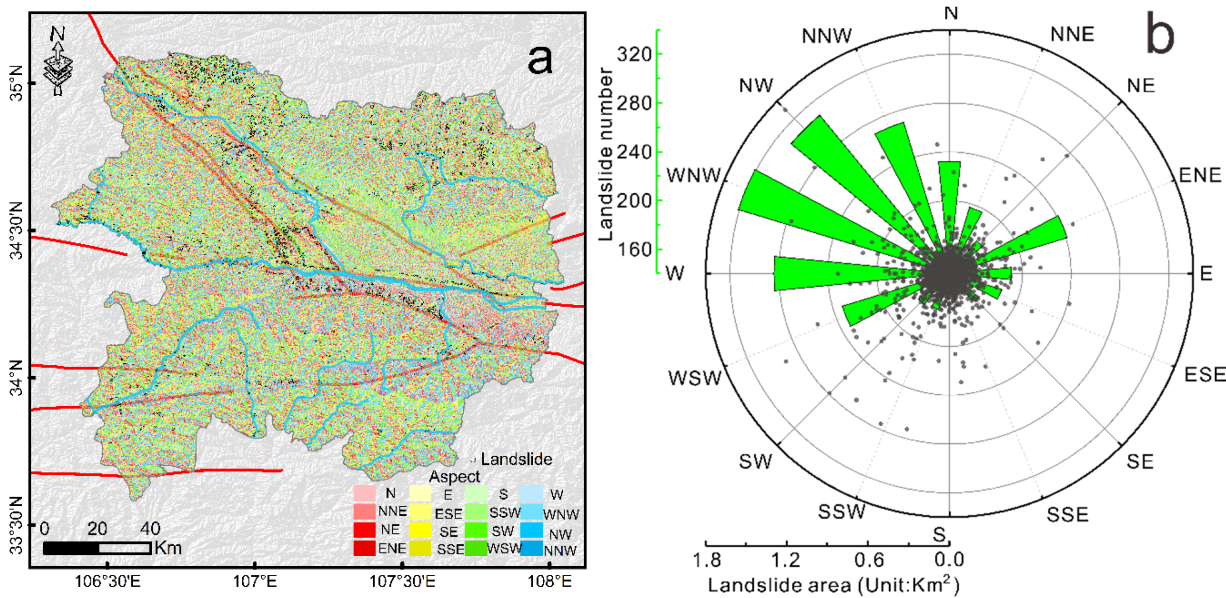

Figure 10. (a) Aspect (slope-facing direction) distribution in the study area. (b) Landslide distribution in respect to aspect and landslide area. 


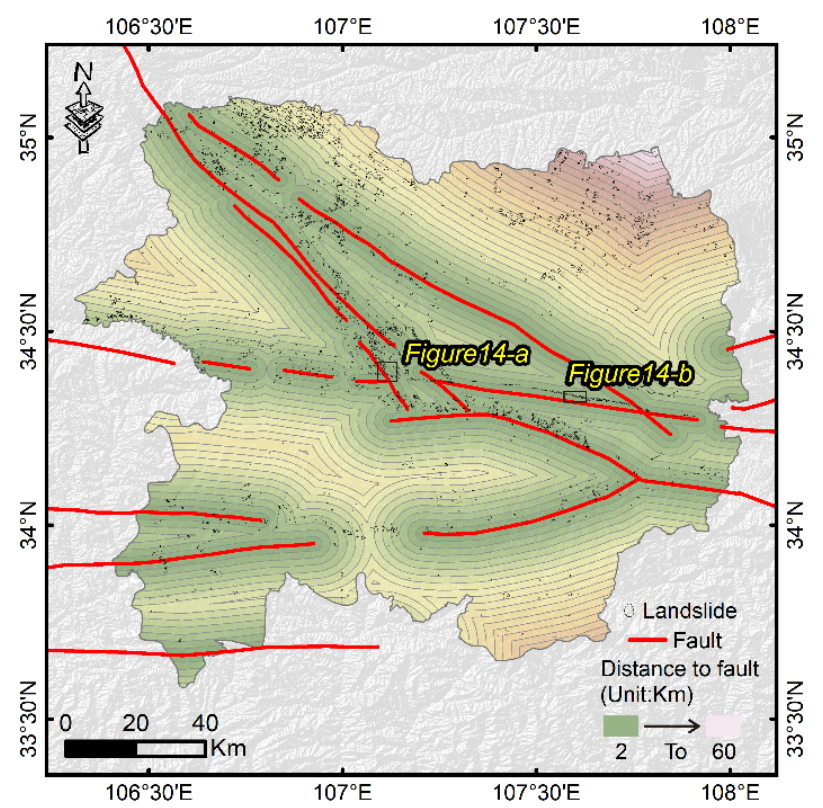

Figure 11. Faults and landslide distribution in the study area.

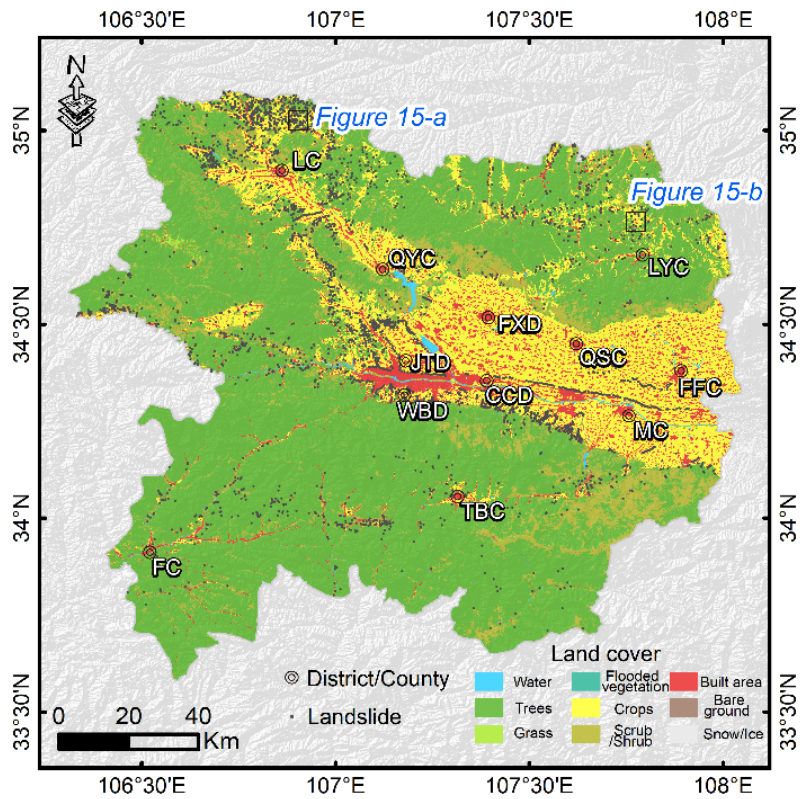

Figure 12. Land cover and landslide distribution in the study area. The districts and counties are shown in Figure 7.

Referring to previous work [47], we chose the landslide number density (LND) and landslide area percentage (LAP) as two indicators of landslide distribution to measure the spatial distribution of landslides in the study area. Of them, LND describes the concentration of landslides, defined as landslide number per $\mathrm{km}^{2}$ (Equation (1)); LAP means the scale of landslides, which is defined as the percentage of landslide area in each factor category (Equation (2)). We can gain initial insight into the subsequent susceptibility map [48] from the statistical results. The extraction of all attributes was done in ArcGIS. The results show that the LND and LAP of the whole study area are $0.19 / \mathrm{km}^{2}$ and $1.98 \%$, respectively, in the study area, the LND distribution map is shown in Figure 13. Table 4 shows the results of LND and LAP for all variables. 


$$
\begin{aligned}
& L N D=\frac{\text { Landslide number }}{\text { Classified area of variable I }} \\
& L A P=\frac{\text { Landslide area }}{\text { Classified area of variable I }}
\end{aligned}
$$

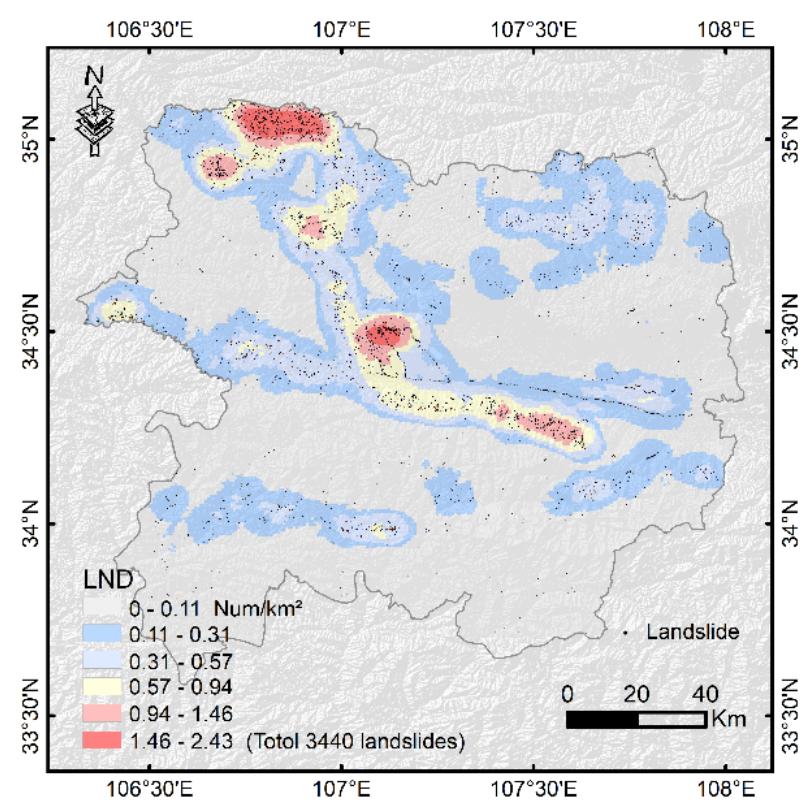

Figure 13. The LND distribution map derived from this study.

\begin{tabular}{|c|c|c|c|c|}
\hline Variable & Classification & Landslide Number & $\mathrm{LND} /\left(\mathrm{km}^{2}\right)$ & LAP \\
\hline Elevation (m) & $400-500$ & 9 & 0.02 & $0.3 \%$ \\
\hline \multirow[t]{14}{*}{$(404-3719)$} & $500-600$ & 265 & 0.31 & $2.4 \%$ \\
\hline & $600-700$ & 372 & 0.37 & $3.8 \%$ \\
\hline & $700-800$ & 298 & 0.36 & $2.8 \%$ \\
\hline & $800-900$ & 305 & 0.35 & $2.8 \%$ \\
\hline & 900-1000 & 329 & 0.31 & $2.7 \%$ \\
\hline & 1000-1100 & 336 & 0.27 & $2.7 \%$ \\
\hline & $1100-1200$ & 455 & 0.31 & $3.9 \%$ \\
\hline & $1200-1300$ & 408 & 0.25 & $3.3 \%$ \\
\hline & $1300-1400$ & 341 & 0.22 & $2.8 \%$ \\
\hline & $1400-1500$ & 142 & 0.12 & $1.1 \%$ \\
\hline & $1500-1600$ & 68 & 0.07 & $0.6 \%$ \\
\hline & $1600-1700$ & 37 & 0.04 & $0.4 \%$ \\
\hline & $1700-1800$ & 40 & 0.04 & $0.4 \%$ \\
\hline & $\cdots$ & & & \\
\hline Slope $\left(^{\circ}\right)$ & $0-10$ & 483 & 0.11 & $2.2 \%$ \\
\hline \multirow[t]{6}{*}{$(0.8-62.1)$} & $10-20$ & 1555 & 0.35 & $3.8 \%$ \\
\hline & $20-30$ & 1047 & 0.21 & $1.4 \%$ \\
\hline & $30-40$ & 311 & 0.1 & $0.6 \%$ \\
\hline & $40-50$ & 36 & 0.05 & $0.2 \%$ \\
\hline & $50-60$ & 7 & 0.06 & $0.3 \%$ \\
\hline & $60-70$ & 1 & 0.06 & $0.3 \%$ \\
\hline
\end{tabular}

Table 4. LND and LAP for each classification of 8 variables. 
Table 4. Cont.

\begin{tabular}{|c|c|c|c|c|}
\hline Variable & Classification & Landslide Number & $\mathrm{LND} /\left(\mathrm{km}^{2}\right)$ & LAP \\
\hline \multirow[t]{16}{*}{ Aspect } & $\mathrm{N}$ & 231 & 0.22 & $1.9 \%$ \\
\hline & NNE & 196 & 0.18 & $1.6 \%$ \\
\hline & $\mathrm{NE}$ & 174 & 0.16 & $1.7 \%$ \\
\hline & ENE & 240 & 0.21 & $2.4 \%$ \\
\hline & E & 190 & 0.16 & $1.7 \%$ \\
\hline & ESE & 184 & 0.15 & $1.4 \%$ \\
\hline & SE & 167 & 0.14 & $1.4 \%$ \\
\hline & SSE & 146 & 0.14 & $1.4 \%$ \\
\hline & S & 154 & 0.16 & $2 \%$ \\
\hline & SW & 170 & 0.16 & $2.5 \%$ \\
\hline & SW & 173 & 0.15 & $2.2 \%$ \\
\hline & WSW & 232 & 0.19 & $2.6 \%$ \\
\hline & W & 284 & 0.25 & $2.4 \%$ \\
\hline & WNW & 321 & 0.29 & $2.7 \%$ \\
\hline & NW & 308 & 0.29 & $2.6 \%$ \\
\hline & NNW & 270 & 0.25 & $1.9 \%$ \\
\hline \multirow[t]{5}{*}{ Position } & Valley & 132 & 0.09 & $0.9 \%$ \\
\hline & Lower mid-slope & 969 & 0.19 & $1.6 \%$ \\
\hline & Mid-slope & 1716 & 0.34 & $3.5 \%$ \\
\hline & Upper mid-slope & 503 & 0.13 & $1.6 \%$ \\
\hline & Ridge & 120 & 0.05 & $1 \%$ \\
\hline \multirow[t]{9}{*}{ Land Cover } & Water & 0 & 0 & 0 \\
\hline & Trees & 1153 & 0.1 & $1 \%$ \\
\hline & Grass & 0 & 0 & 0 \\
\hline & Flooded vegetation & 0 & 0 & 0 \\
\hline & Crops & 1383 & 0.39 & $4.8 \%$ \\
\hline & Scrub/Shrub & 795 & 0.38 & $4 \%$ \\
\hline & Built area & 104 & 0.1 & $1 \%$ \\
\hline & Bare ground & 5 & 0.33 & $2 \%$ \\
\hline & Snow and ice & 0 & 0 & 0 \\
\hline \multirow[t]{12}{*}{ Strata } & $\mathrm{Q}$ & 1995 & 0.29 & $3.4 \%$ \\
\hline & $N \& E$ & 158 & 0.32 & $3.6 \%$ \\
\hline & $\mathbf{K}$ & 589 & 0.42 & $3.7 \%$ \\
\hline & $\mathrm{J}$ & 1 & 0.09 & $2.2 \%$ \\
\hline & $\mathrm{T}$ & 12 & 0.03 & $0.6 \%$ \\
\hline & $\mathrm{P}$ & 4 & 0.03 & $0.1 \%$ \\
\hline & $\mathrm{C}$ & 20 & 0.06 & $0.9 \%$ \\
\hline & $\mathrm{D}$ & 196 & 0.1 & $0.8 \%$ \\
\hline & $S$ & 0 & 0 & 0 \\
\hline & $\mathrm{O}$ & 41 & 0.25 & $1.7 \%$ \\
\hline & $\epsilon$ & 24 & 0.13 & $1.2 \%$ \\
\hline & $P t$ & 12 & 0.09 & $0.7 \%$ \\
\hline \multirow[t]{7}{*}{ Distance to stream (m) } & 200 & 170 & 0.15 & $0.7 \%$ \\
\hline & 400 & 361 & 0.33 & $3.2 \%$ \\
\hline & 600 & 238 & 0.23 & $3 \%$ \\
\hline & 800 & 237 & 0.23 & $3.2 \%$ \\
\hline & 1000 & 236 & 0.24 & $2.4 \%$ \\
\hline & 1200 & 196 & 0.2 & $1.8 \%$ \\
\hline & $\cdots$ & & & \\
\hline \multirow[t]{8}{*}{ Distance to fault $(\mathrm{km})$} & 2 & 852 & 0.34 & $2.9 \%$ \\
\hline & 4 & 724 & 0.3 & $2.5 \%$ \\
\hline & 6 & 355 & 0.17 & $1.7 \%$ \\
\hline & 8 & 243 & 0.14 & $1 \%$ \\
\hline & 10 & 200 & 0.14 & $1.2 \%$ \\
\hline & 12 & 195 & 0.15 & $1.3 \%$ \\
\hline & 14 & 154 & 0.13 & $1.6 \%$ \\
\hline & 16 & 129 & 0.13 & $1.7 \%$ \\
\hline
\end{tabular}

\section{Results}

\subsection{Overall Distribution Characteristics of Large Landslides}

The distribution of large landslides in Baoji presents two characteristics: unevenness (or a strong spatially non-uniform pattern) and aggregation. The former is reflected in that the number of the landslides is much higher in the north than in the south throughout 
the study area, while there is no such a feature in the horizontal direction. Landslides are sparsely distributed in the southeast of this area, with several dense landslide areas in the northwestern part. In areas where a large number of landslides occurred, there is also an obvious zonal and aggregated distribution of slope failures, of which the former (Figure 14a) is located near the Longxian-Baoji fault in the Jintai District on the north bank of the Wei River, and the latter (Figure 15a) in the affected area of the Longxian earthquake (Figure 2).
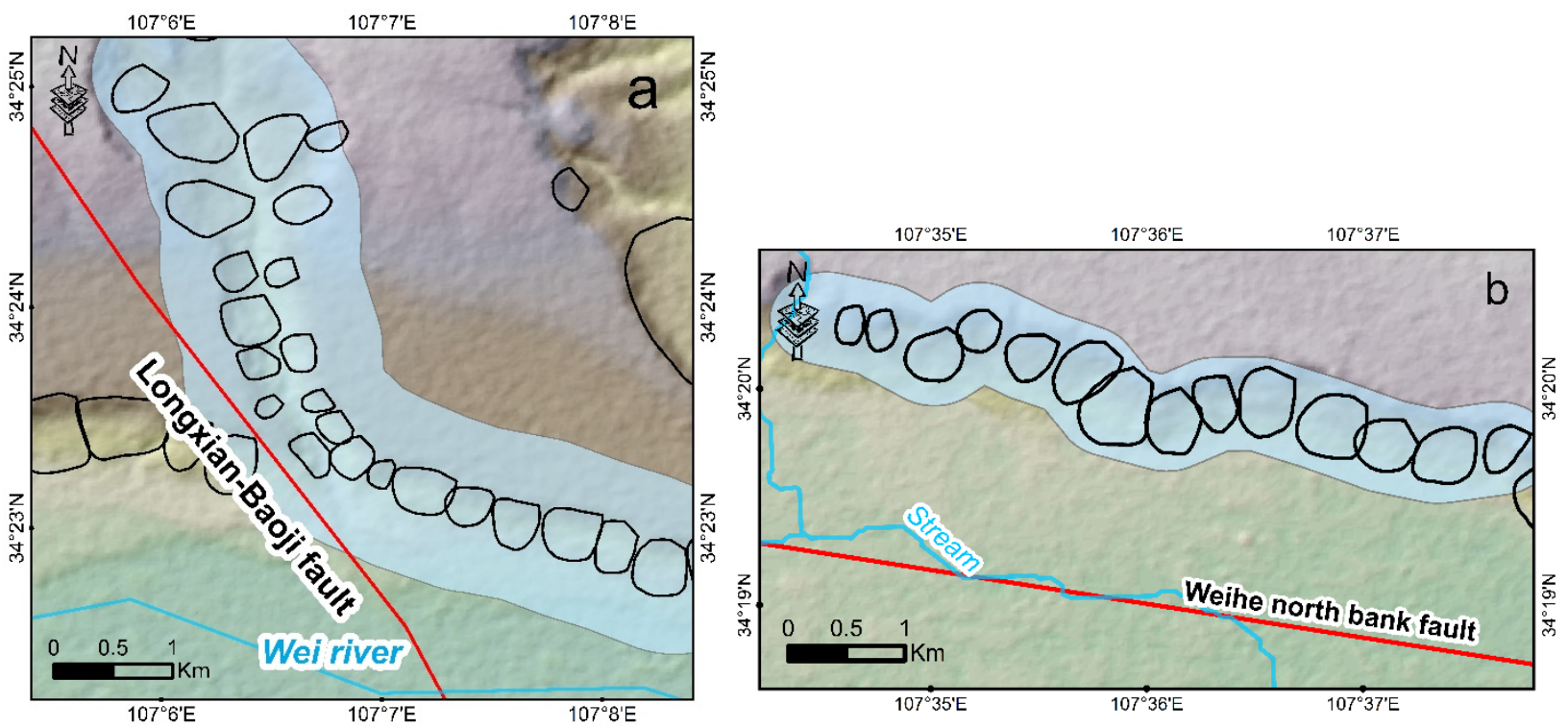

Figure 14. Typical 'landslide zone' in the study area. The black irregular polygon represents a single landslide, and the light blue area represents a concentrated landslide development zone. The locations of $(\mathbf{a}, \mathbf{b})$ are shown in Figure 11.
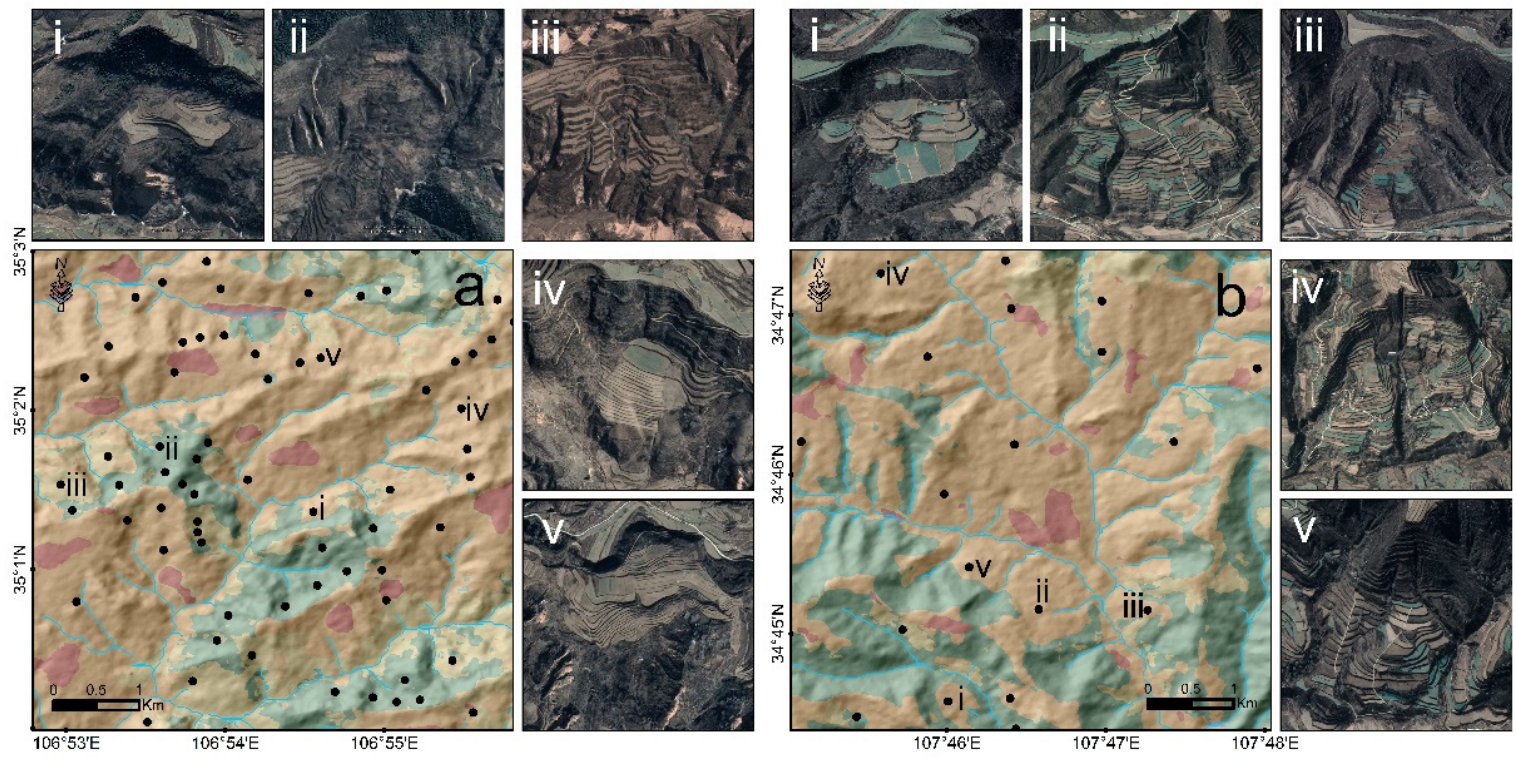

Figure 15. Typical 'landslide aggregation zone' in the study area. The black point represents a single landslide, and the surrounding remote sensing images are five typical landslides. The locations of $(\mathbf{a}, \mathbf{b})$ are shown in Figure 12.

\subsection{Correlation between Landslides and Influencing Factors}

This work analyzed the relationship between landslides and influence factors such as topography and geology. The statistical results from this analysis are shown in Figure 16. 

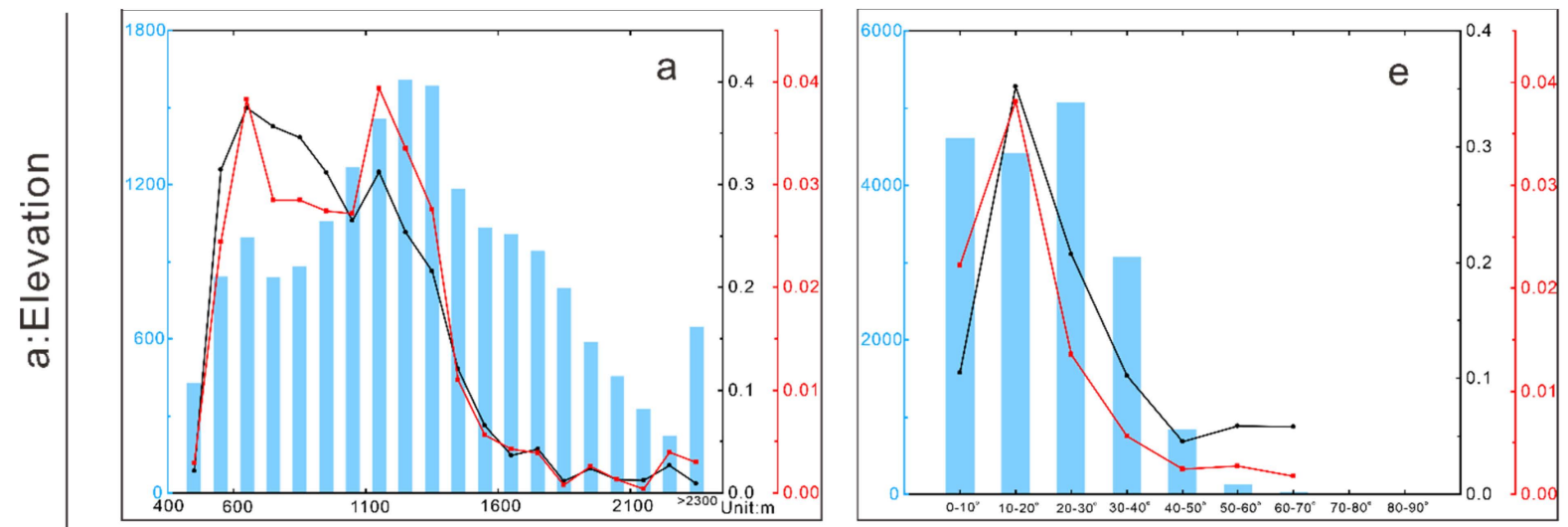

$\frac{0}{\stackrel{0}{0}}$
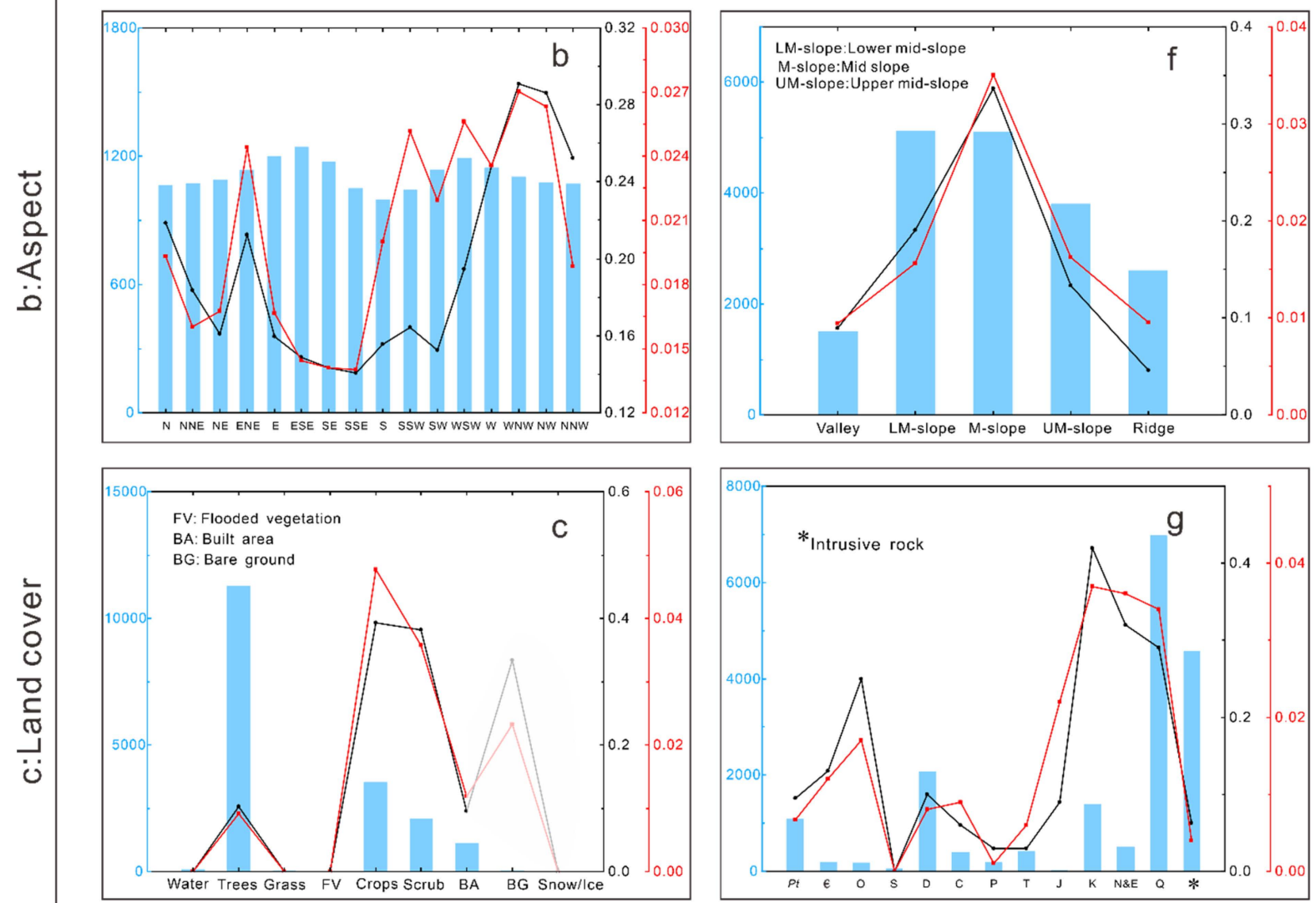

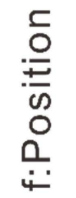
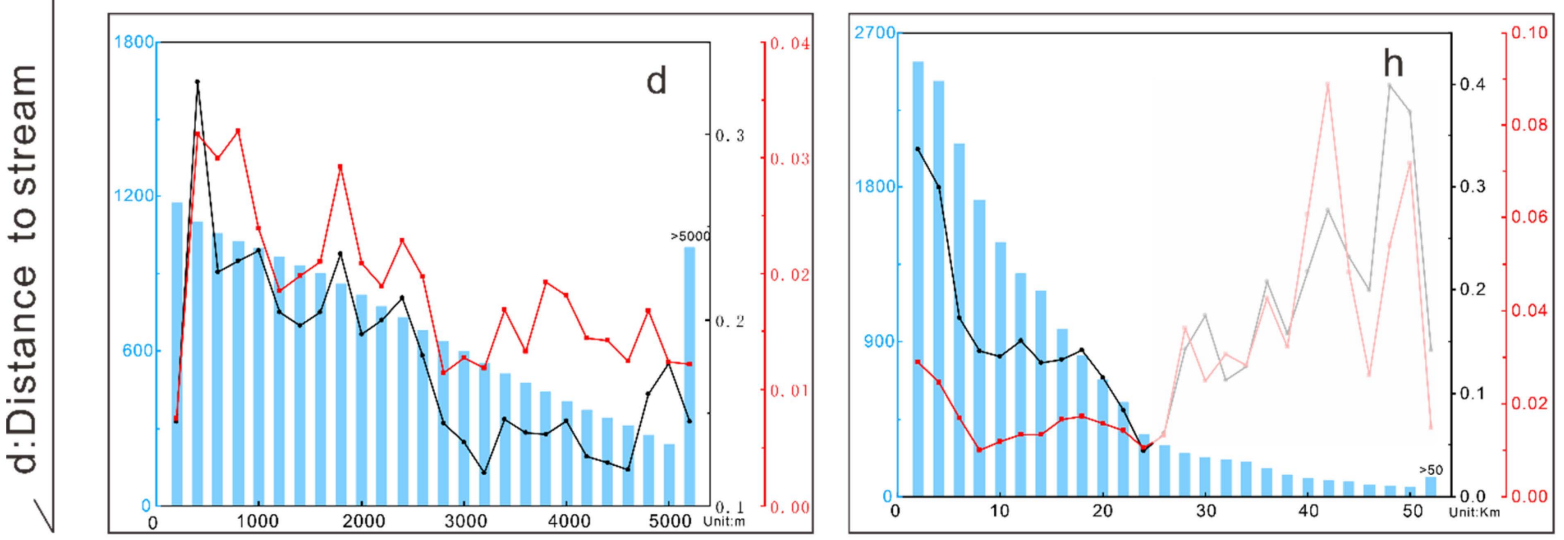

望

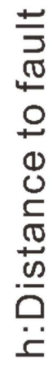

Figure 16. Classified areas of eight influencing factors in the study area (blue bars) and curves of LND and LAP versus these areas. 


\subsubsection{Topographic Factors}

The elevation of the study area ranges from 404 to $3719 \mathrm{~m}$, divided at $100 \mathrm{~m}$ intervals in this work. Statistics show that most of the landslides are located at elevations from 500 to $1400 \mathrm{~m}$, accounting for $94.2 \%$ of the total. In the range of elevations greater than $1800 \mathrm{~m}$, there are only 45 landslides, although the land area occupies $16.7 \%$ of the study area. The peak values of LND and LAP are $0.37 / \mathrm{km}^{2}$ and $3.9 \%$ at $600-700 \mathrm{~m}$ and $1100-1200 \mathrm{~m}$, respectively (Figure 16a).

Slope means the degree of steepness of the surface unit, which determines the exposed face when a landslide occurs to some extent. The slope of the study area ranges from 0.8 to $62.1^{\circ}$ and was divided into $10^{\circ}$ intervals in this work. The area of the interval less than $40^{\circ}$ occupies $94.6 \%$ of the total, among which the number of landslide development in the $10-20^{\circ}$ interval is the largest, 1555 , where the LND and LAP also reach their peak at $0.35 / \mathrm{km}^{2}$ and $3.8 \%$, respectively (Figure $16 \mathrm{e}$ ). The statistics show no case that the higher the slope is, the more likely landslides are to occur.

The slope aspect (facing direction) has a great effect on the mountain ecology, thus affecting the occurrence of landslides. The area of 16 aspect divisions in the study area is approximately equal. The peaks of both LND and LAP appear in the WNW direction with $0.29 / \mathrm{km}^{2}$ and $2.7 \%$, respectively. In general, the LAP values of west-facing slopes are significantly larger than those of east-facing slopes, and the average landslide size is also slightly larger than that of east-facing slopes.

Slope position links to the landform feature may also affect the occurrence of landslides. There is a positive correlation between the area of landslides and the area of slope location division in the study area, generally showing a trend of first increasing and then decreasing. There are 1716 landslides on the middle slope, with LND and LAP of $0.34 / \mathrm{km}^{2}$ and $3.5 \%$, respectively.

The influence of land-use types on the occurrence of landslides is also obvious. Four main land types exist in the study area: trees, crops, shrub and built area. Among them, the area covered by trees occupies $62.6 \%$ of the total, with 1153 landslides. There are 1383 landslides in the areas covered by crops, where both LND and LAP reach the peaks of $0.39 / \mathrm{km}^{2}$ and $4.8 \%$, respectively, implying landslide-prone areas (Figure 16c).

\subsubsection{Geological Factors}

In the study district, the area of loess-dominated Quaternary and granite-dominated intrusive rocks is the largest, occupying $60.8 \%$ of the total, where the landslides mainly developed in loess sediments, with 1995 landslides identified. From the Cretaceous to the Quaternary strata, large LND and LAP values are present, with peaks of $0.42 / \mathrm{km}^{2}$ and $3.7 \%$ in the Cretaceous, indicating a major influence of loess and sandy conglomerates on the occurrence of landslides.

Active faults are closely related to genesis of earthquakes, thus affecting seismic landslides. Figure $16 \mathrm{~h}$ shows that faults have obvious influence on the occurrence of landslides. There are 3046 landslides developed within $20 \mathrm{~km}$ from the fault, accounting for $88.3 \%$ of the total, and the LND shows a decreasing trend as the distance to the fault increases. The peaks of both LND and LAP appear at the closest location to the fault, with $0.34 / \mathrm{km}^{2}$ and $2.9 \%$, respectively. Although LND and LAP fluctuate somewhat at $20 \mathrm{~km}$ away from the fault, the total number of landslides occupies only $11.7 \%$, meaning that the degree of influence is relatively weak.

\subsubsection{Hydrological Factors}

The study area hosts several tributaries of the Wei River that is a major stream in Shaanxi. There are 531 landslides developed within $400 \mathrm{~m}$ from the stream. LND and LAP show a gradual decrease in the range of 200-1200 $\mathrm{m}$ to the stream. LND reaches the maximum value of $0.33 / \mathrm{km}^{2}$ in the distance range of $200-400 \mathrm{~m}$ to the stream, and LAP reaches the maximum value of $3.2 \%$ in the range of $600-800 \mathrm{~m}$ (Figure 16d). 


\section{Discussion}

\subsection{Landslide Inventory}

For the identification of large landslides in Baoji, we mainly referred to the existing standards for manual interpretation of remote sensing images $[4,49,50]$. The methods used in this study include the following: (1) Based on the basic outline of typical landslides, including steep walls at the back edge of landslides, sidewalls, undulating topography at the front edge, irregular stepped distribution on landslides, and the formation of weirs by landslide blockage [51], we established the interpretation marks of large landslides in the study area. (2) Using multi-period high-resolution satellite imagery from Google Earth, acquired from 2000 to 2021, we identified key parts of landslides based on interpretation experiences, and used polygons to circle the spatial extent of single landslides. (3) By comparing the landslide locations recorded in the existing literature (Table 3), the landslides we interpreted earlier were further checked so as to produce a relatively complete database of large landslides. Considering that the force source mechanisms that generate landslides include pushing and traction [52], we used the centroid of landslides (Figure 6a) to count the spatial distribution pattern of landslides. Xu et al. [53] adopted the same method to count the co-earthquake landslides by the 2008 Wenchuan earthquake, indicating that the results are objective and accurate.

\subsection{Spatial Distribution of Large Landslides}

As Xu et al. [54] mentioned, there is some clustering of landslides in the study area, but our results do not conform to the characteristic of dense landslides in the south and gradual sparseness toward the north. Le et al. [55] suggested that the basin edge, river bank, terrace edge, fault zone, and town surroundings tend to be zones of aggregation of landslides in loose soils, which can be seen in Figures 6 and 11. The intense neo-tectonic movements and accompanying paleoclimatic environmental changes are the primary driving force for the formation of river systems in the Loess Plateau, where rivers flow from northwest to southeast along the terrain [56]. The Wei River is the main stream in the study area, with numerous tributaries (Figure 8). Landslides are concentrated on both sides of this river valley and the intersection of several rivers, where the LND is as high as $0.33 / \mathrm{km}^{2}$ within 200 to $400 \mathrm{~m}$ from the stream, which can be explained by differential lifting and lowering movements of the crust in the Loess Plateau after the Tertiary time that led to the instability of slopes caused by erosion [57]. In addition, earthquakes as a typical representative of the neotectonic movement, might have resulted in the "flaky" dense distribution of landslides in loose soils, which is also reflected in this study. For instance, an earthquake with Ms6.0 in 1704 was recorded in Long County, northwest corner of Baoji, where many old landslides are present around the earthquake area (Figure 14a). With reference Peng et al. [24], the study area can also be zoned according to the location of large landslides, and such subsequent work needs to be done based on further collection of detailed geological data.

\subsection{Correlation between Landslides and Influencing Factors}

The geological structure of Baoji is complex, with many fault zones in the territory, such as the Qinling North Edge fault zone. The Wei River is the main stream in the study area, with numerous tributaries, and the land around the twelve districts and counties in the territory has been greatly reformed (Figure 12).

The study area is dominated by low-middle elevations; most landslides occurred in the regions with elevations of $500 \mathrm{~m}$ to $1400 \mathrm{~m}$, accounting for $94.2 \%$ of the total, which is in good agreement with $\mathrm{Hu}$ [58]. The reason may be that these areas have accumulated many loose deposits, which are easy to slide under external disturbance. From this work, the peak value of LND is $0.37 / \mathrm{km}^{2}$ at elevations $600-700 \mathrm{~m}$, likely due to the effect of streams there. 
Every indicator reaches their peaks in the range of slope $10^{\circ}$ to $20^{\circ}$, and the number of landslides shows a decreasing trend as the slope increases, consistent with the conclusion obtained by $\mathrm{Xu}$ et al. [59].

For the aspect (Figure 10), the largest number of landslides is in the WNW and NW directions, with the peaks of both LND and LAP occurring in the WNW direction. We note that the orientation of several faults within the northern margin of the Qinling North Edge fault zone is close to the dominant sliding direction of the landslides, which leads to the conclusion that the slope aspect has a strong controlling on the occurrence of landslides. Qiu et al. [60] obtained similar results by coupling the relationship between the occurrence of landslides in loose soils and slope aspect. They also found that the aspect effect varied with the type of landforms: the more mature the development of geomorphology, the more obvious the slope aspect effect on the landslides. Hu [58] analyzed 6627 landslides on the Loess Plateau; however, he found that there is not much correlation between landslides and the aspect, probably because he did not ensure the completeness of the landslides in the area involved. Therefore, it is necessary to construct a complete regional landslide database.

With the position of a slope from low to high, LND and LAP show a trend of first increasing and then decreasing; meanwhile, the number of landslides reaches the maximum in the middle slope, which is likely the result of the joint influence of the elevation and river (Figure 17b). The Quaternary strata are the largest area exposed, occupying $38.4 \%$ of the total area of the study area, mainly distributed in the plains and basins on the north bank of the Wei River, followed by granite-based intrusive rocks occupying $25.2 \%$ of the area. The number of landslides in the Quaternary loess-covered strata is the largest, with 1995, consistent with $\mathrm{Xu}$ et al. [23].
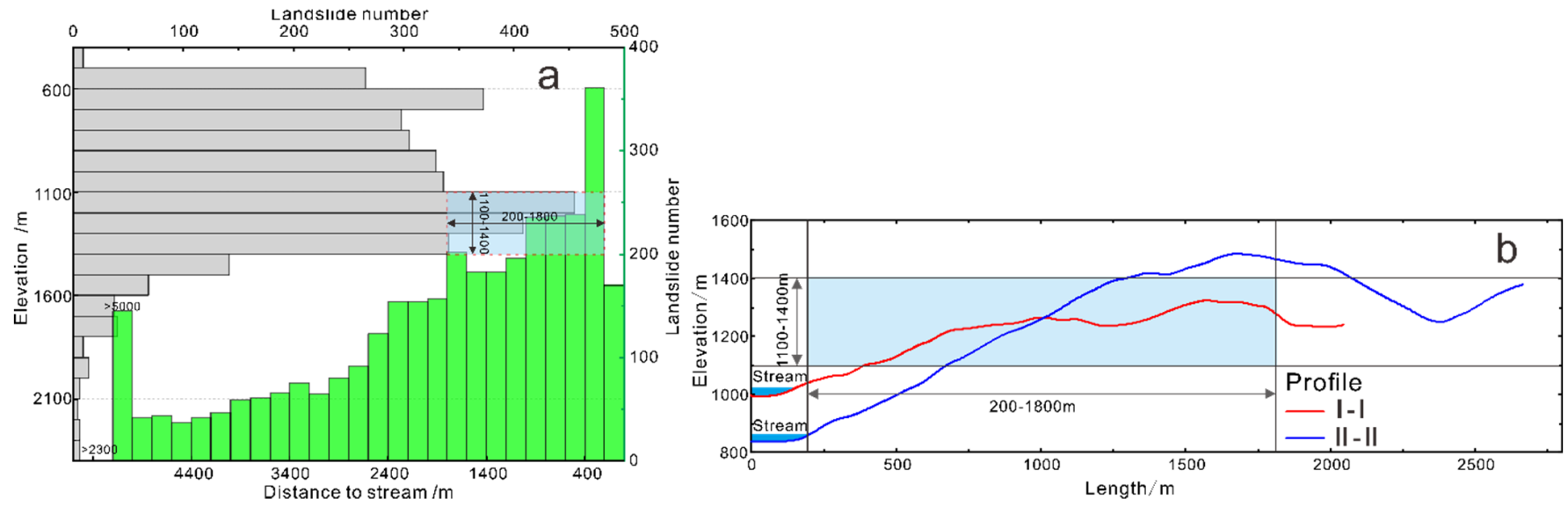

Figure 17. The influence of the elevation and distance to the stream on the landslide concentration. (a) The distribution of landslides per elevation class. (b) Corresponding hill profiles, the locations I-I and II-II are shown in Figure 7.

From the Cretaceous to the Quaternary, large LND and LAP values occur in each stratum for the following reasons: (1) Sandstone within the Cretaceous strata, which was the product of alluvial fan and fluvial deposits, is unstable. (2) Shales and marls in Tertiary have small strength, prone to softening and swelling after soaking in water. (3) The loess layer in Quaternary is loose and permeable, and the underlying bedrock is relatively watertight, so the water is collected in the weak rock layer, softening the beds and forming a sliding zone, most likely to trigger a "dual structure" (loess-bedrock) landslide [61].

Active faults have obvious influence on the occurrence of landslides: 3046 landslides developed within $20 \mathrm{~km}$ from the faults, occupying $88.3 \%$ of the total, and the LND shows a decreasing trend as the distance to the faults increases. Peng et al. [62] analyzed the Liujiabao landslide, which occurred under the influence of loess-mudstone stratigraphy, faults, seismic forces and heavy rainfall. Moreover, their extensive investigations found 
that such a geological background and climatic condition are common in northwest China, which provide favorable conditions for large-scale landslides in this region.

The study area is dominated by crops in addition to the area covered by trees, which occupied $30.2 \%$ of the total area, and the building area accounts for $9.7 \%$ of the total. There are 1383 landslides developed in the area covered by crops, where both LND and LAP reach their maximum values. Figure 12 shows the location where landslides are concentrated, indicating that landslides are directly related to human activities, especially agricultural irrigation. The residents of Loess Plateau have long been engaged in agricultural irrigation for, which poses an influence on the groundwater in the loess plateau area, resulting in a continuous rise of the water level, which gradually deforms the soil at the foot of the slope and leads to the instability of the slope [63]. The most typical affected area of such landslides is the Hefangtai area in Lanzhou City [64].

The number of landslides is mostly within the distance of 200 to $400 \mathrm{~m}$ to the stream, which tends to decrease as the distance increases. As the largest tributary of the Yellow River, the Wei River has well-developed drainage that has created a heavily eroded valley landscape in the study area. The sand content of the Wei River is gradually decreasing in the study area, for which the reasons are as follows: after the Wei River entered the Guanzhong Plain from the Baoji Gorge, the valley suddenly released, and the bed slope decreased greatly, which led to the decrease in the sediment-carrying capacity of the water flow. This further intensified the scouring on both sides of the river, leading to changes in the composition and structure of the slope body and causing landslides.

\subsection{Comparison with Existing Landslide Databases}

The study area, Baoji, is located at the southwest edge of the Loess Plateau, and we attempted to make some qualitative and quantitative comparative analyses based on this paper and the published literature involving the spatial distribution of landslides in Baoji. Firstly, Peng et al. [24] mapped the distribution of landslides on the Loess Plateau, including 14,544 landslides, and divided the Loess Plateau into eight landslide zones. In his study, the maximum LND, $0.18 / \mathrm{km}^{2}$, was obtained in the Haiyuan seismic area, compared to the average LND of $0.19 / \mathrm{km}^{2}$ in our study; thus, it seemed that although each landslide mentioned by Peng possessed more detailed geological information, his database was clearly incomplete. A similar study was conducted by $\mathrm{Hu}$ [58], but he only selected 6627 typical landslides of the Loess Plateau for mapping landslide distribution, and the LND of Baoji was $0.0141 / \mathrm{km}^{2}$, which is far lower than the results of our study. In addition, although $\mathrm{Xu}$ et al. [23] compiled a database of landslides on the Loess Plateau containing more than 80,000 landslides, the regions he covered were mainly distributed in the four extremely seismic areas of Hongdong, Huaxian, Tongwei, and Haiyuan, and the area affected by the 2010 Tianshui rainstorm event. His study did not include the distribution of landslides within the entire city of Baoji; the 4122 landslides in Shaanxi Province mentioned by Zhuang et al. [24] were similar.

Secondly, the literature with Baoji as the study area was of great help to this study and is listed as follows: The 392 large loess landslides in Baoji mentioned by $\mathrm{Xu}$ et al. [29], with an average area of 47.18 million $\mathrm{m}^{2}$ and the approximate geographical locations of the landslides, could be obtained from his paper, which provided a good reference for our interpretation as well as cross-checking. Shi et al. [65] analyzed the causes of more than 70 landslides in a small area of Jintai District, Baoji city; Figure 13a shows a part of his study. $\mathrm{Xu}$ et al. [39] analyzed the distribution pattern of the geological hazard in the area from Long County to Qianyang in the northwest of Baoji city, and proposed five concentrated distribution areas and six concentrated distribution zones. The detailed locations of the hazards were in good agreement with our interpretation, and the LND was $0.181 / \mathrm{km}^{2}$, which was close to our study. It could be seen that the database of geological hazards in small areas built by $\mathrm{Xu}$ et al. [39] was very complete. Most of the remaining literature deals only with the detailed analysis of single landslides within Baoji, as shown in Table 3. 


\section{Conclusions}

Based on Google Earth and remote sensing imagery, this work prepared an inventory of large-scale landslides in the Baoji city, Shaanxi Province, China. In total, 3440 landslides were identified, of which the largest individual is $1,709,700 \mathrm{~m}^{2}$, the smallest is $634.5 \mathrm{~m}^{2}$, and the average area is $104,198 \mathrm{~m}^{2}$. We chose the landslide number density (LND) and landslide area percentage (LAP) as evaluation indicators and conducted statistical analysis on the correlation between the landslides and influencing factors. The results show that LND and LAP are $0.19 / \mathrm{km}^{2}$ and $1.98 \%$, respectively. The landslides are more likely to occur in the elevation range of 500-1400 $\mathrm{m}$. The LND and LAP reach their peaks at slopes of 10-20 . Slopes facing WNW and NW are close to most of the orientation of faults, which are the dominant area of landslides. Middle and lower slopes exhibit high landslide susceptibility. LND and LAP show a general trend of decreasing with increasing distance to the fault and stream, followed by a slow rebound. There are more landslides in the areas covered by crops, compared to other regions. For lithology, areas covered by Quaternary loess and Cretaceous gravels are the main areas where landslides occurred. Compared with relevant previous work, the database of large-scale landslides within Baoji obtained in this study is more complete. However, our current work is very superficial, and we need to conduct more in-depth research in some aspects. We believe that the following aspects should be the focus of the next research, which are subdivided as follows: (1) the landslide susceptibility mapping in Baoji; (2) to conduct more detailed investigations, including the types of landslides [66], the morphology of the landslide bodies, etc.; and (3) to analyze the occurrence mechanism and triggering factors of typical landslides based on the previous information. Overall, our results provide necessary support for various subsequent studies.

Author Contributions: Chong $\mathrm{Xu}$ proposed the research concept, organized the landslide interpretation, and provided basic data. Lei Li designed the framework and wrote the manuscript. Xiwei $\mathrm{Xu}$, Zhongjian Zhang and Jia Cheng provided basic data. All authors have read and agreed to the published version of the manuscript.

Funding: This study was supported by the National Institute of Natural Hazards, Ministry of Emergency Management of China (ZDJ2020-14) and the Lhasa National Geophysical Observation and Research Station (NORSLS20-07).

Institutional Review Board Statement: Not applicable.

Informed Consent Statement: Not applicable.

Acknowledgments: We are grateful to the anonymous reviewers for their constructive comments and suggestions that improved the quality of the manuscript.

Conflicts of Interest: The authors declare no conflict of interest.

\section{References}

1. Huang, F.; Chen, J.; Du, Z.; Yao, C.; Huang, J.; Jiang, Q.; Chang, Z.; Li, S. Landslide susceptibility prediction considering regional soil erosion based on machine-learning models. Int. J. Geo-Inf. 2020, 9, 377. [CrossRef]

2. Moharrami, M.; Naboureh, A.; Gudiyangada, N.; Thimmaiah; Ghorbanzadeh, O.; Guan, X.; Blaschke, T. National-scale landslide susceptibility mapping in Austria using fuzzy best-worst multi-criteria decision-making. Int. J. Geo-Inf. 2020, 9, 393. [CrossRef]

3. Kim, J.-W.; Lu, Z.; Qu, F.; Hu, X. Pre-2014 mudslides at Oso revealed by Insar and multi-source dem analysis. Geomat. Nat. Hazards Risk 2015, 6, 184-194. [CrossRef]

4. $\mathrm{Xu}, \mathrm{C} . ; \mathrm{Xu}, \mathrm{X}$. Construction of basic earthquake-triggered landslides dataset for several large earthquake events at the beginning of the twenty-first century. Seismol. Geol. 2014, 36, 90-104. (In Chinese)

5. Guzzetti, F.; Carrara, A.; Cardinali, M.; Reichenbach, P. Landslide hazard evaluation: A review of current techniques and their application in a multi-scale study, Central Italy. Geomorphology 1999, 31, 181-216. [CrossRef]

6. Piacentini, D.; Troiani, F.; Daniele, G.; Pizziolo, M. Historical geospatial database for landslide analysis: The catalogue of landslide occurrences in the emilia-romagna region (CLOCkER). Landslides 2018, 15, 811-822. [CrossRef]

7. Sapir, D.G.; Misson, C. The development of a database on disasters. Disasters 1992, 16, 74-80. [CrossRef]

8. Kirschbaum, D.; Stanley, T.; Zhou, Y. Spatial and temporal analysis of a global landslide catalog. Geomorphology 2015, $249,4-15$. [CrossRef] 
9. Stanley, T.; Kirschbaum, D.B. A heuristic approach to global landslide susceptibility mapping. Nat. Hazards 2017, 87, 145-164. [CrossRef]

10. Ohmori, H.; Sugai, T. Toward geomorphometric models for estimating landslide dynamics and forecasting landslide occurrence in Japanese mountains. Z. Geomorphol. 1995, 101, 149-164.

11. Van Den Eeckhaut, M.; Hervás, J. State of the art of national landslide databases in Europe and their potential for assessing landslide susceptibility, hazard and risk. Geomorphology 2012, 139-140, 545-558. [CrossRef]

12. Pennington, C.; Freeborough, K.; Dashwood, C.; Dijkstra, T.; Lawrie, K. The national landslide database of Great Britain: Acquisition, communication and the role of social media. Geomorphology 2015, 249, 44-51. [CrossRef]

13. Taylor, F.E.; Malamud, B.D.; Freeborough, K.; Demeritt, D. Enriching great Britain's national landslide database by searching newspaper archives. Geomorphology 2015, 249, 52-68. [CrossRef]

14. Damm, B.; Klose, M. The landslide database for Germany: Closing the gap at national level. Geomorphology 2015, $249,82-93$. [CrossRef]

15. Guzzetti, F. Landslide fatalities and the evaluation of landslide risk in Italy. Eng. Geol. 2000, 58, 89-107. [CrossRef]

16. Sabatakakis, N.; Koukis, G.; Vassiliades, E.; Lainas, S. Landslide susceptibility zonation in Greece. Nat. Hazards 2013, 65, 523-543. [CrossRef]

17. Tonini, M.; Pecoraro, G.; Romailler, K.; Calvello, M. Spatio-temporal cluster analysis of recent Italian landslides. Georisk Assess. Manag. Risk Eng. Syst. Geohazards 2020, 1-19. [CrossRef]

18. Denys, B. Mass movement; the research frontier and beyond: A geomorphological approach. Geomorphology 1993, 7, 85-128.

19. Xu, C.; Xu, X.; Shyu, J.B.H.; Gao, M.; Tan, X.; Ran, Y.; Zheng, W. Landslides triggered by the 20 April 2013 Lushan, China, mw 6.6 earthquake from field investigations and preliminary analyses. Landslides 2015, 12, 365-385. [CrossRef]

20. Pike, R.J. The geometric signature: Quantifying landslide-terrain types from digital elevation models. Math. Geol. 1988, 20, 491-511. [CrossRef]

21. Xu, J.; Xu, C.; He, X.; Wen, B.; Ge, K.; Bai, Y. Spatial distribution of seismic landslides in the areas of 1927 Gulang M8.0 earthquake. Earthq. Res. China 2020, 34, 5-28.

22. Peng, J.; Wang, S.; Wang, Q.; Zhuang, J.; Huang, W.; Zhu, X.; Leng, Y.; Ma, P. Distribution and genetic types of loess landslides in China. J. Asian Earth Sci. 2019, 170, 329-350. [CrossRef]

23. Xu, Y.; Allen, M.B.; Zhang, W.; Li, W.; He, H. Landslide characteristics in the loess plateau, northern China. Geomorphology 2020, 359, 107-150. [CrossRef]

24. Zhuang, J.; Peng, J.; Wang, G.; Javed, I.; Wang, Y.; Li, W. Distribution and characteristics of landslide in loess plateau: A case study in Shaanxi province. Eng. Geol. 2018, 236, 89-96. [CrossRef]

25. Wei, X.; Zhang, M.; Xiao, P. Developmental characteristic, regularities of distribution of the slide, which is a geological disaster, in Baota district of Yan'an city. Shanxi Archit. 2006, 32, 115-116. (In Chinese)

26. Shi, J.; Li, B.; Wu, S.; Wang, T.; Xin, P. Mechanism of large-scale slide at edge of Loess Plateau on north of weihe river in Baoji urban area, Shaanxi Province. J. Eng. Geol. 2013, 6, 938-949. (In Chinese)

27. Zhao, B.; Huang, Y.; Zhang, C.; Wang, W.; Tan, K.; Du, R. Crustal deformation on the Chinese mainland during 1998-2014 based on GPS data. Geod. Geodyn. 2015, 6, 7-15. [CrossRef]

28. Deng, Q.; Cheng, S.; Ma, J.; Du, P. Seismic activities and earthquake potential in the Tibetan Plateau. Chin. J. Geophys. 2014, 57, 2025-2042.

29. Xu, L.; Yan, D.; Zhao, T. Probabilistic evaluation of loess landslide impact using multivariate model. Landslides 2020, 18, 1011-1023. [CrossRef]

30. Xu, C.; Wu, Y.; Xu, X. Earthquake-triggered landslides in the loess plateau and its adjacent areas. J. Eng. Geol. 2018, 26 (Suppl. 1), 260-273. (In Chinese)

31. Xu, C.; Tian, Y.; Ma, S.; Xu, X.; Zhou, B.; Wu, X.; Zhuang, J.; Gao, Y.; Wu, W.; Huang, X. Inventory and spatial distribution of landslides in IX-XI high intensity areas of 1920 Haiyuan (China) M8.5 earth-quake. J. Eng. Geol. 2018, 26, 1188-1196. (In Chinese)

32. Cui, Y.; Bao, P.; Xu, C.; Ma, S.; Zheng, J.; Fu, G. Landslides triggered by the 6 September 2018 mw 6.6 Hokkaido, Japan: An updated inventory and retrospective hazard assessment. Earth Sci. Inform. 2020, 14, 247-258. [CrossRef]

33. Rabby, Y.W.; Li, Y. An integrated approach to map landslides in Chittagong hilly areas, Bangladesh, using google earth and field mapping. Landslides 2018, 16, 633-645. [CrossRef]

34. Crosby, C. Lidar and Google Earth: Simplifying access to high-resolution topography data. Spec. Pap. Geol. Soc. Am. 2012, 492, 37-47.

35. Shao, X.; Xu, C.; Ma, S.; Zhou, Q. Effects of seismogenic faults on the predictive mapping of probability to earthquake-triggered landslides. Int. J. Geo-Inf. 2019, 8, 328. [CrossRef]

36. $\mathrm{Xu}, \mathrm{C}$. Preparation of earthquake-triggered landslide inventory maps using remote sensing and gis technologies: Principles and case studies. Geosci. Front. 2015, 6, 825-836. [CrossRef]

37. Cruden, D.; Varnes, D.J. Landslide Types and Processes; National Academy Press: Washington, DC, USA, 1996.

38. Shao, X.; Ma, S.; Xu, C.; Shen, L.; Lu, Y. Inventory, distribution and geometric characteristics of landslides in Baoshan city, Yunnan province, China. Sustainability 2020, 12, 2433. [CrossRef]

39. Xu, G.; Zheng, D.; Li, S.; Qiao, Z.; Cong, N. Remote sensing images and distribution characteristics of avalanche and landslide geohazards in the western part of the Weibei Plateau, Shaanxi Province, China. Geol. Bull. China 2008, 27, 1837-1845. (In Chinese) 
40. Meng, J.; Hu, Q.; Shi, J.; Xin, P.; Li, B.; Wang, T. Research on basic features and stability of large and deep-seated loess landslide on the north bank of the weihe river in Baoji area. J. Geomech. 2018, 24, 78-86. (In Chinese)

41. Xin, P.; Hu, L.; Wang, T.; Fan, L.; Wu, S.; Shi, J. The application of displacement-stress synergetic analysis to landslide monitoring: A case study of Beipo landslides in Baoji City, Shaanxi Province. Acta Geosci. Sin. 2020, 41, 37-48. (In Chinese)

42. Wang, C. Study on Formation Mechanism and Stability of Loess Landslide in Beipo Village of Didian County, Baoji City. Master's Thesis, Xi'an Technological University, Xi'an, China, 2019.

43. Wang, H.; Zhou, B.; Wu, S.; Shi, J.; Li, B. Characteristic analysis of large-scale loess landslides: A case study in Baoji City of Loess Plateau of northwest China. Nat. Hazards Earth Syst. Sci. 2011, 11, 1829-1837. [CrossRef]

44. Yang, G.; Xu, P.; Cao, C.; Zhang, W.; Lan, Z.; Chen, J.; Dong, X. Assessment of regional landslide susceptibility based on combined model of certainty factor method. J. Eng. Geol. 2019, 27, 1153-1163. (In Chinese)

45. Andrew, K.S. Terrain position as mapped from a gridded digital elevation model. Int. J. Geogr. Inf. Sci. 1990, 4, $33-49$.

46. Deng, Q.; Cheng, S.; Ma, J.; Du, P. Seismic activities and earthquake potential in the Tibetan Plateau. Chin. J. Geophys. 2014, 57, 678-697. (In Chinese) [CrossRef]

47. Xu, C.; Ma, S.; Tan, Z.; Xie, C.; Toda, S.; Huang, X. Landslides triggered by the 2016 Mj 7.3 Kumamoto, Japan, earthquake. Landslides 2017, 15, 551-564. [CrossRef]

48. Ciurleo, M.; Calvello, M.; Cascini, L. Susceptibility zoning of shallow landslides in fine grained soils by statistical meth-ods. Catena 2016, 139, 250-264. [CrossRef]

49. Parker, R.N.; Densmore, A.L.; Rosser, N.J.; Michele, M.; Li, Y.; Huang, R.; Whadcoat, S.; Petley, D.N. Mass wasting triggered by the 2008 Wenchuan earthquake is greater than orogenic growth. Nat. Geosci. 2011, 4, 449-452. [CrossRef]

50. Harp, E.L.; Keefer, D.K.; Sato, H.P.; Yagi, H. Landslide inventories: The essential part of seismic landslide hazard analyses. Eng. Geol. 2011, 122, 9-21. [CrossRef]

51. Xu, Y.; Du, P.; Li, W.; Zhang, W.; Tian, Q.; Xiong, R.; Wang, L. A case study on AD 1718 Tongwei M 7.5 earthquake triggered landslides-application of landslide database triggered by historical strong earthquakes on the Loess Plateau. Chin. J. Geophys. 2020, 63, 1235-1248. (In Chinese)

52. Qiao, D.; Li, Z. Engineering Geology in Loess Areas; Water Resources and Electric Power Press: Beijing, China, 1990. (In Chinese)

53. Xu, C.; Xu, X.; Wu, X.; Dai, F.; Yao, X.; Yao, Q. Detailed catalog of landslides triggered by the 2008 Wenchuan earthquake and statistical analyses of their spatial distribution. J. Eng. Geol. 2013, 21, 25-44. (In Chinese)

54. Xu, Z.; Lin, Z.; Zhang, M. Loess in China and loess landslides. Chin. J. Rock Mech. Eng. 2007, 26, 1297-1312. (In Chinese)

55. Le, Z. The distribution pattern of geological hazards and its application. J. Gansu Sci. 1996, 8, 123-128. (In Chinese)

56. Lei, X. Models of loess stratigraphical structure on the terraces in the Loess Plateau of China. Mar. Geol. Quat. Geol. 2006, 2, 113-122. (In Chinese)

57. Wang, N. Study on the Growing Laws and Controlling Measures for Loess Landslide. Ph.D. Thesis, Chengdu University of Technology, Chengdu, China, 2004. (In Chinese)

58. Hu, S. Spatial Pattern of Landslide in Loess Plateau and Its Influence on Geomorphologic Evolution. Ph.D. Thesis, Northwest University, Xi'an, China, 2019. (In Chinese)

59. Tian, Y.; Xu, C.; Xu, X.; Chen, J. Detailed inventory mapping and spatial analyses to landslides induced by the $2013 \mathrm{~ms} 6.6$ Minxian earthquake of China. J. Earth Sci. 2016, 27, 1016-1026. [CrossRef]

60. Qiu, H.; Regmi, A.D.; Cui, P.; Hu, S.; Wang, Y.; He, Y. Slope aspect effects of loess slides and its spatial differentiation in different geomorphologic types. Arab. J. Geosci. 2017, 10, 344. [CrossRef]

61. Duan, Z.; Li, W.; Wang, Q. Types and spatial-temporal distribution of loess landslides in the south plateau of lower Jing river. J. Xi'an Univ. Sci. Technol. 2015, 35, 369-375. (In Chinese)

62. Peng, J.; Leng, Y.; Zhu, X.; Wu, D.; Tong, X. Development of a loess-mudstone landslide in a fault fracture zone. Environ. Earth Sci. 2016, 75, 658. [CrossRef]

63. Peng, J.; Wu, D.; Duan, Z.; Tang, D.; Cheng, Y.; Che, W.; Huang, W.; Wang, Q.; Zhuang, J. Disaster characteristics and destructive mechanism of typical loess landslide cases triggered by human engineering activities. J. Southwest Jiaotong Univ. 2016, 51, 971-980. (In Chinese)

64. Xu, L.; Dai, F.; Tu, X.; Tham, L.G.; Zhou, Y.; Iqbal, J. Landslides in a loess platform, north-west China. Landslides 2013, 11, 993-1005. [CrossRef]

65. Shi, J.; Wu, L.; Wu, S.; Li, B.; Wang, T.; Xin, P. Analysis of the causes of large-scale loess landslides in Baoji, China. Geomorphology 2016, 264, 109-117. [CrossRef]

66. Peng, D.; Xu, Q.; Liu, F.; He, Y.; Zhang, S.; Qi, X.; Zhao, K.; Zhang, X. Distribution and failure modes of the landslides in Heit-ai terrace, China. Eng. Geol. 2018, 236, 97-110. [CrossRef] 